\title{
Role of 2-series prostaglandins in the pathogenesis of type 2 diabetes mellitus and non-alcoholic fatty liver disease (Review)
}

\author{
WEIXUAN WANG ${ }^{1-4^{*}}, \mathrm{XIN} \mathrm{ZHONG}^{1-4^{*}}$ and JIAO GUO ${ }^{1-4}$ \\ ${ }^{1}$ Guangdong Metabolic Diseases Research Center of Integrated Chinese and Western Medicine, \\ Guangdong Pharmaceutical University; ${ }^{2}$ Key Laboratory of Glucolipid Metabolic Disorder, \\ Ministry of Education of China; ${ }^{3}$ Institute of Chinese Medicine, Guangdong Pharmaceutical University; \\ ${ }^{4}$ Guangdong TCM Key Laboratory for Metabolic Diseases, Guangzhou, Guangdong 510006, P.R. China
}

Received December 4, 2020; Accepted March 24, 2021

DOI: $10.3892 /$ ijmm.2021.4947

\begin{abstract}
Nowadays, metabolic syndromes are emerging as global epidemics, whose incidence are increasing annually. However, the efficacy of therapy does not increase proportionately with the increased morbidity. Type 2 diabetes mellitus (T2DM) and non-alcoholic fatty liver disease (NAFLD) are two common metabolic syndromes that are closely associated. The pathogenic mechanisms of T2DM and NAFLD have been studied, and it was revealed that insulin resistance, hyperglycemia, hepatic lipid accumulation and inflammation markedly contribute to the development of these two diseases. The 2-series prostaglandins (PGs), a subgroup of eicosanoids, including $\mathrm{PGD}_{2}, \mathrm{PGE}_{2}, \mathrm{PGF}_{2 \alpha}$ and $\mathrm{PGI}_{2}$, are converted from arachidonic acid catalyzed by the rate-limiting
\end{abstract}

Correspondence to: Professor Jiao Guo, Guangdong Metabolic Diseases Research Center of Integrated Chinese and Western Medicine, Guangdong Pharmaceutical University, Room 403, 4th Floor, Science and Technology Building, 280 Waihuan East Road, Guangzhou Higher Education Mega, Guangzhou, Guangdong 510006, P.R. China

E-mail: gyguoyz@163.com

*Contributed equally

Abbreviations: AA, arachidonic acid; Akt, serine/threonine kinase; apoB, apolipoprotein B; cAMP, cyclic adenosine monophosphate; COX, cyclooxygenase; GSIS, glucose-stimulated insulin secretion; HFD, high-fat diet; IL, interleukin; MCP-1, monocyte chemoattractant protein-1; NAFLD, non-alcoholic fatty liver disease; NASH, non-alcoholic steatohepatitis; NEFAs, non-esterified fatty acids; NF- $\kappa \mathrm{B}$, nuclear factor- $\kappa \mathrm{B}$; NSAIDs, nonsteroidal anti-inflammatory drugs; PI3K, phosphatidylinositol 3-kinase; PKC, protein kinase C; PKA, protein kinase A; PG, prostaglandin; PPAR, peroxisome proliferator-activated receptor; PUFAs, polyunsaturated fatty acids; TNF- $\alpha$, tumor necrosis factor $\alpha$; T2DM, type 2 diabetes mellitus; TG, triglyceride; VLDL, very low-density lipoprotein; WAT, white adipose tissue

Key words: prostaglandin, type 2 diabetes mellitus, non-alcoholic fatty liver disease, insulin resistance, hyperglycemia, hepatic lipid accumulation, inflammation enzymes cyclooxygenases (COXs). Considering their wide distribution in almost every tissue, 2-series PG pathways exert complex and interlinked effects in mediating pancreatic $\beta$-cell function and proliferation, insulin sensitivity, fat accumulation and lipolysis, as well as inflammatory processes. Previous studies have revealed that metabolic disturbances, such as hyperglycemia and hyperlipidemia, can be improved by treatment with COX inhibitors. At present, an accumulating number of studies have focused on the roles of 2-series PGs and their metabolites in the pathogenesis of metabolic syndromes, particularly T2DM and NAFLD. In the present review, the role of 2-series PGs in the highly intertwined pathogenic mechanisms of T2DM and NAFLD was discussed, and important therapeutic strategies based on targeting 2-series PG pathways in T2DM and NAFLD treatment were provided.

\section{Contents \\ 1. Introduction \\ 2. PG biosynthesis \\ 3. PGs and insulin resistance \\ 4. PGs and hyperglycemia \\ 5. PGs and hepatic lipid accumulation \\ 6. PGs and inflammation \\ 7. Conclusion and future perspectives}

\section{Introduction}

Type 2 diabetes mellitus (T2DM) and non-alcoholic fatty liver disease (NAFLD), two common metabolic syndromes, are emerging as global epidemics, whose incidence are rising annually $(1,2)$. T2DM is predominantly characterized by an assembly of hyperglycemia, hyperinsulinemia, insulin resistance and insulin deficiency (3). According to the Diabetes Atlas 9th edition published by the International Diabetes Federation (IDF), 463 million adults aged 20-79 years are suffering from diabetes mellitus worldwide, with the prevalence of diabetes mellitus in that age group being $\sim 9.3 \%$, and the total number of diabetic patients predicted to rise to 700 million (10.9\%) by 2045 (1). In total, $>90 \%$ of 
the diabetic patients belong to T2DM, as estimated by IDF. NAFLD, currently the most common chronic liver disease, covers a wide disease spectrum, ranging from simple steatosis to non-alcoholic steatohepatitis (NASH), hepatic fibrosis, cirrhosis and hepatocellular carcinoma (HCC), which finally causes liver-associated mortality (4). A meta-analysis on NAFLD epidemiology reported a global prevalence of $25.24 \%$ in 2016 (2). In China, the prevalence has risen from $25.4 \%$ in 2008-2010 to $32.3 \%$ in 2015-2018 (5).

T2DM and NAFLD are closely associated. According to clinical data, the overall incidence of NAFLD is $55.5 \%$ among patients with T2DM (6), and NAFLD is an independent risk factor for T2DM, indicating a strong bi-directional relationship between T2DM and NAFLD $(7,8)$. T2DM is a risk factor for progression from simple steatosis to NASH and advanced fibrosis. T2DM is associated with a high morbidity of NASH $(9,10)$. Patients with simple steatosis often have a benign prognosis, whereas NASH can progress to cirrhosis, with patients eventually developing $\operatorname{HCC}(11,12)$. The prevalence of HCC is $~ 5$-fold higher when the disease progresses from simple steatosis to NASH, leading to a markedly higher mortality rate $(13,14)$. In addition, the presence of NAFLD in patients with T2DM is highly associated with the incidence of macro- and micro-vascular diabetic complications (15). It is harder to control blood glucose levels in patients with T2DM with NAFLD, compared with patients with only T2DM (16). Both T2DM and NAFLD can be caused by metabolic disorders, and share familiar or even the same risk factors and pathological mechanisms. Although studies have shown that the existing pathogenic mechanisms of T2DM and NAFLD include insulin resistance, hyperglycemia, hepatic lipid accumulation and inflammation (17-19), due to the multifaceted and intricate correlations between these two diseases, the underlying molecular mechanisms require further exploration.

Both T2DM and NAFLD can be largely influenced by dietary structure. The intake of Western diet contributes to the onset and development of T2DM and NAFLD (20-22). A Western diet is mainly characterized by high amounts of saturated fatty acids (such as palmitic acid), simple carbohydrates (corn syrup and fructose), low levels of polyunsaturated fatty acids (PUFAs; n-6 and n-3 PUFAs), and insufficient intake of protein and dietary fibers $(22,23)$. In addition, there is a high intake of n-6 PUFAs (particularly linoleic acid) and a low intake of n-3 PUFAs [such as $\alpha$-linolenic acid (ALA)] in this dietary pattern among patients with T2DM and NAFLD, which cause a high ratio of n-6/n-3 PUFAs (24). The intake of Western diets results in an increased level of n-6-PUFA-derived arachidonic acid (AA) and subsequent eicosanoid production [particularly 2-series prostaglandins (PGs)], and there is a decreased level of those derivatives from n-3 PUFAs in patients with T2DM and NAFLD (25-27). Decreased n-3 PUFAs, which are partly caused by an impaired ALA desaturation in the liver, can repress fatty acid oxidation and contribute to pro-lipogenic outcome by downregulating peroxisome proliferator-activated receptor- $\alpha$ (PPAR- $\alpha$ ); they can also promote lipogenic and glycogenic capacity by upregulating sterol regulatory element-binding protein 1c (SREBP-1c) (24). Furthermore, the downregulation of PPAR- $\alpha$ by $n-3$ PUFAs depletion activates the nuclear factor- $\kappa \mathrm{B}(\mathrm{NF}-\kappa \mathrm{B})$ and activating protein 1 in the liver, leading to a pro-inflammatory effect in patients with
NAFLD (24). On the other hand, the increased n-6 PUFAs and its derivatives can influence the inflammatory state and disturb glucose and lipid metabolism (28-32). Linoleic acid can alter fatty acid transportation, mitochondrial function, inflammatory responses and oxidative stress by increasing PG release and activating PPAR- $\gamma$, interleukin- 8 (IL-8) and the NF- $\kappa \mathrm{B}$ signaling pathway $(30,32)$. The $\mathrm{J} 2$-series $\mathrm{PGs}$ can promote adipocyte differentiation by directly activating PPAR- $\gamma$ (31). Therefore, n-6 PUFAs and n-3 PUFAs exert various vital metabolic effects, and the levels of n-6 and n-3 PUFAs, which can be mediated by similar dietary patterns of T2DM and NAFLD (particularly a Western diet) are important for the pathological development of these two diseases.

As important derivatives of n-6 PUFAs, 2-series PGs are widely distributed in almost every tissue. In the PG synthesis pathway, four principal bioactive 2-series PGs are generated, including $\mathrm{PGD}_{2}, \mathrm{PGE}_{2}, \mathrm{PGF}_{2 \alpha}$ and $\mathrm{PGI}_{2}$ (33). Clinical and experimental evidence has indicated that 2-series PGs are involved in the initiation and progression of numerous diseases, including diabetes mellitus (34), hypertension (35), obesity (36), fatty liver disease (37), vascular diseases (38), carcinoma (39), inflammatory bowel disease (40), rheumatoid arthritis (41), asthma and allergic diseases (42) and Alzheimer's disease (43). Studies have revealed that 2-series PGs play complex and interlinked roles in mediating metabolic homeostasis and systemic chronic inflammation (34,44-48). Moreover, 2-series PGs have bidirectional effects on insulin secretion and pancreatic $\beta$-cell proliferation during hyperglycemia (34). As PPAR- $\gamma$ modulators, 2 -series PGs regulate adipogenesis and lipolysis in lipid metabolism, leading to excessive fat deposit (44-46). In addition, 2-series PGs are involved in immune response by affecting various cytokines and immune cells, such as macrophages and monocytes, under insulin resistance, hyperlipidemic and diabetic status $(44,47,48)$. Of note, the nonsteroidal anti-inflammatory drugs (NSAIDs) and cyclooxygenase-2-selective inhibitors (COXIBs) can interfere with 2-series PG synthesis by inhibiting cyclooxygenases (COXs), and have been widely used in anti-inflammation, analgesia, antiplatelet aggregation and anti-tumorigenesis treatment (49-51). However, the potential application of NSAIDs and COXIBs in the treatment of T2DM and NAFLD requires further investigation.

To the best of our knowledge, 2-series PGs play an important role in the development of T2DM and NAFLD. However, few studies have focused on the therapeutic effect of targeting the 2-series PG pathway in these two metabolic syndromes. Herein, the way in which 2-series PGs exert multifunctional effects on the highly intertwined pathogenesis of T2DM and NAFLD, including insulin resistance, hyperglycemia, hepatic lipid accumulation and inflammation, were systematically reviewed, and it was revealed that targeting the 2-series PG pathway may be an important therapeutic strategy in T2DM and NAFLD treatment.

\section{PG biosynthesis}

PGs belong to eicosanoids and have 1-, 2- and 3-series homologues. Each series of PGs is biosynthesized from different PUFAs, including dihomo- $\gamma$-linolenic acid (DGLA), AA and eicosapentaenoic acid (EPA) (52). DGLA is catalyzed by COXs 
to produce 1-series PGs (such as $\mathrm{PGE}_{1}, \mathrm{PGG}_{1}$ and $\mathrm{PGD}_{1}$ ), and can also be converted to AA by the enzyme $\Delta^{5}$ desaturase (53). AA is the precursor of multiple important bioactive lipid mediators, including the 2-series PGs (such as $\mathrm{PGE}_{2}, \mathrm{PGD}_{2}$, $\mathrm{PGF}_{2 \alpha}$ and $\mathrm{PGI}_{2}$ ) lipoxins, leukotrienes, resolvins, protectins and maresins (54).

To the best of our knowledge, the 1-series metabolites may be less closely associated with the correlation between T2DM and NAFLD, since a limited number of studies have been conducted. Furthermore, the 3-series PGs (such as $\mathrm{PGF}_{30}$ and $\mathrm{PGE}_{3}$ ) produced by EPA generally have a lower biological activity than their 1- and 2-series homologues (55). Therefore, the present review focused on the 2-series PGs that are the principal PGs derived from AA with a biological significance in T2DM and NAFLD.

The synthesis of 2-series PGs is precisely regulated (Fig. 1). Apart from being produced from DGLA, AA is mainly derived from cellular membrane phospholipids. Membrane phospholipids are esterified by $\mathrm{PLA}_{2} \mathrm{~S}$ to generate free AA. AA is subsequently converted to $\mathrm{PGG}_{2}$, followed by a peroxidase reaction that immediately reduces $\mathrm{PGG}_{2}$ to $\mathrm{PGH}_{2}$ by the rate-limiting enzymes COXs (56). COXs mainly have two isoforms, COX-1 and COX-2. COX-1 is a constitutive isoform expressed in most tissues and involved in most physiological events, while COX-2 is highly expressed in response to physical, chemical and inflammatory stimuli (57). However, COX-2 is constitutively expressed in several tissues that are not associated with inflammation, such as the brain, kidney, thymus and gut $(58,59)$. Then, $\mathrm{PGH}_{2}$ is metabolized to $\mathrm{PGE}_{2}$, $\mathrm{PGD}_{2}, \mathrm{PGF}_{2 \alpha}$ and $\mathrm{PGI}_{2}$ through different $\mathrm{PG}$ synthases $(56,60)$. Next, a wide variety of PGs exert their biological functions by binding to their respective $G$ protein-coupled receptors. $\mathrm{PGE}_{2}$ is converted from $\mathrm{PGH}_{2}$ by PGE synthase (PGES) and performs pleiotropic effects by binding to four distinct membrane PGE receptors (EP1-4). PGD synthases, including lipocalin-type PGDS (L-PGDS) and hematopoietic PGDS (H-PGDS), catalyze the isomerization of $\mathrm{PGH}_{2}$ to $\mathrm{PGD}_{2}$, which binds to PGD receptors (DP1 and DP2). $\mathrm{PGI}_{2}$, an agonist of PGI receptor (IP), is generated by PGI synthase. $\mathrm{PGF}_{2 \alpha}$ is converted by PGF synthase and binds to PGF receptor (FP) (33).

The synthesized 2-series PGs affect various physiological and pathological processes, particularly the important pathogenesis of T2DM and NAFLD, which includes insulin resistance, hyperglycemia, hepatic lipid accumulation and inflammation (Fig. 2) (17-19). In the next section, the role of PGs in these pathogenic mechanisms will be further reviewed (Fig. 3).

\section{PGs and insulin resistance}

Insulin resistance is regarded as a key pathogenic mechanism that accounts for the interplay between T2DM and NAFLD. Insulin resistance is characterized by an impaired insulin sensitivity of liver and peripheral tissues, including skeletal muscle and adipose tissue. It is a crucial contributor to the other related pathogeneses, which includes hyperinsulinemia, hyperglycemia, dyslipidemia, ectopic lipid accumulation (such as in the liver) and inflammation (Fig. 2) (61). More specifically, first, insulin resistance contributes to hyperglycemia. Hepatic insulin resistance markedly increases hepatic glucose production, while peripheral insulin resistance enhances circulating non-esterified fatty acids (NEFAs) and decreases glucose uptake, together leading to elevated glycemia (62-65). Secondly, hepatic de novo lipogenesis, a primary initiation mechanism of liver fat formation, is facilitated by compensatory hyperinsulinemia and increased substrates (such as glucose and NEFAs) under insulin-resistant status in liver (64). Thirdly, insulin resistance is of great significance in the steatosis-to-NASH progression, as it is closely linked to aggravated inflammation, apoptosis and fibrogenesis in the liver (66). As for peripheral insulin resistance, adipose insulin resistance also triggers chronic low-grade inflammation by the release of adipokines and cytokines, which in turn maintains or even exacerbates the development of T2DM and NAFLD $(67,68)$.

Accumulating evidence has revealed the important role of 2-series PGs in the development of insulin resistance (Fig. 3A) (37). Herein, the role of 2-series PGs in both hepatic and peripheral insulin resistance was discussed.

Hepatic insulin resistance. Hepatic insulin resistance is the key pathophysiological event during the development of T2DM and NAFLD, which is characterized by suppressed glycogenesis, increased gluconeogenesis and glycogenolysis, and augmented de novo lipogenesis (62-64). Insulin signaling has a different effect on hepatic glucose and lipid metabolism. Under insulin resistance, glucose metabolism becomes resistant to insulin action, while lipid metabolism remains sensitive to insulin or even enhanced by hyperinsulinemia (69). In combination, these metabolic alterations enhance hepatic glucose production, finally leading to hyperglycemia and liver lipid accumulation.

PGs have a dual effect on mediating hepatic insulin signaling; however, their impact remains inconclusive. These metabolites can be generated in hepatocytes, such as parenchymal hepatocytes (70) and Kupffer cells (71), acting as negative mediators for insulin signaling. Previous experimental research has shown that the use of COX-2 inhibitors in an obese rat model resulted in decreased PGE metabolites and improved systemic insulin sensitivity by increasing glucose uptake, repressing hepatic glucose production and decreasing hepatic triglyceride (TG) contents (37). Furthermore, $\mathrm{PGE}_{2}$ can disrupt hepatic insulin signaling, which most likely resembles the IL-6-induced interference on insulin signaling (72). Via $\mathrm{EP} 3$ receptor, $\mathrm{PGE}_{2}$ activates extracellular signal-regulated kinase $1 / 2$ (ERK1/2) and subsequently promotes serine phosphorylation of insulin receptor substrate (IRS) 1 . This finally prevents glycogen synthesis in cultured hepatocytes by interfering with insulin-dependent serine/threonine kinase (Akt) activation (72). Another study revealed that $\mathrm{PGE}_{2}$-induced oncostatin M (OSM) production in liver Kupffer cells attenuated insulin-dependent IRS/PI3K/Akt signaling, leading to a repressed glucokinase expression and increased TG accumulation in hepatocytes (71). The intrinsic mechanism is that increased OSM promotes phosphorylation of signal transducer and activator of transcription 3 (STAT3) to induce transcription of cytokine signaling 3 (SOCS3) (71). Consistent with in vitro results, this mechanism is also responsible for the development of hepatic insulin resistance, steatosis and elevated plasma glucose level in murine NAFLD models. It is recommended 


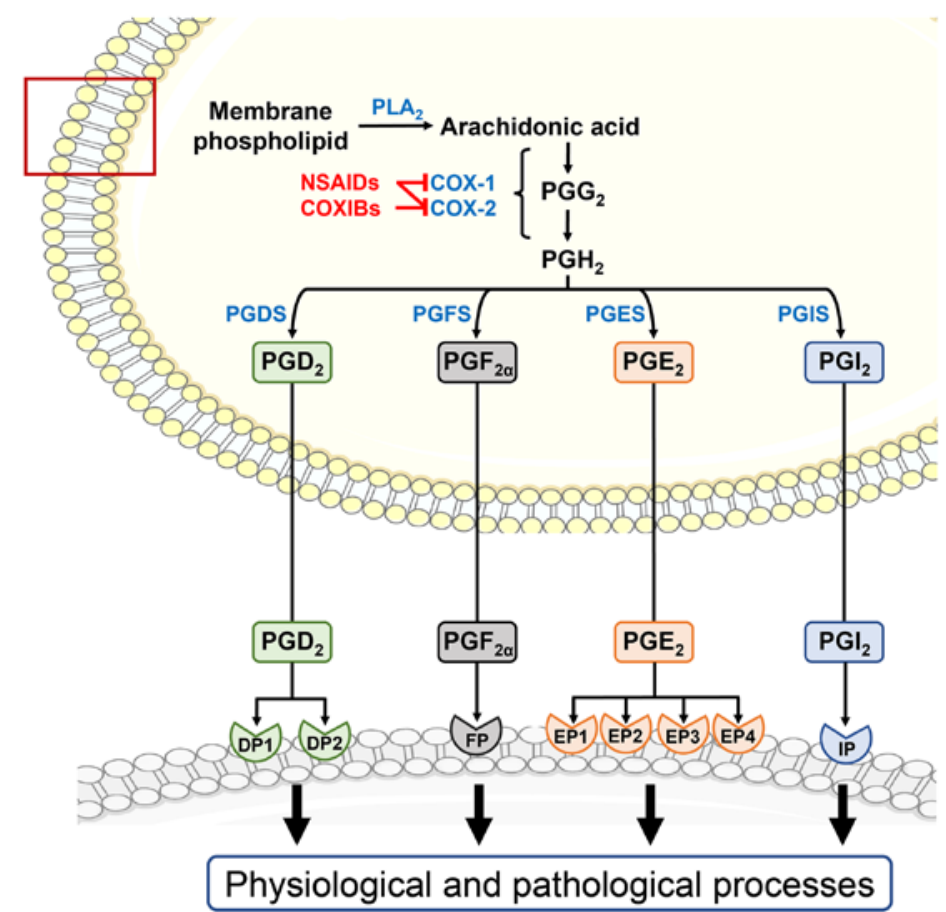

Figure 1. Overview of 2-series PG biosynthesis pathways. AA is generated by PLA from membrane phospholipids. Both COX-1 and COX-2 convert AA to $\mathrm{PGG}_{2}$ and subsequently $\mathrm{PGH}_{2}$. $\mathrm{PGH}_{2}$ is metabolized by different PG synthases (PGDS, PGFS, PGES and PGIS) to produce $\mathrm{PGD}_{2}, \mathrm{PGF}_{2 a}, \mathrm{PGE}_{2}$ and $\mathrm{PGI}_{2}$, respectively. PGs act by binding to their specific receptors, including PGD receptors (DP1-2), PGF receptor (FP), PGE receptors (EP1-4) and PGI receptor (IP), and are involved in various physiological and pathological processes. AA, arachidonic acid; $\mathrm{PLA}_{2}$, phospholipase $\mathrm{A}_{2}$; COX, cyclooxygenase; PG, prostaglandin; $\mathrm{PGG}_{2}$, prostaglandin $\mathrm{G}_{2} ; \mathrm{PGH}_{2}$, prostaglandin $\mathrm{H}_{2} ; \mathrm{PGD}_{2}$, prostaglandin $\mathrm{D}_{2} ; \mathrm{PGF}_{2 \alpha}$, prostaglandin $\mathrm{F}_{2 \alpha} ; \mathrm{PGE}_{2}$, prostaglandin $\mathrm{E}_{2} ; \mathrm{PGI}_{2}$, prostacyclin; DP1-2, $\mathrm{PGD}$ receptor 1-2; FP, PGF receptor; EP1-4, PGE receptor1-4; IP, PGI receptor; PGDS, PGD synthase; PGFS, PGF synthase; PGES, PGE synthase; PGIS, PGI synthase.

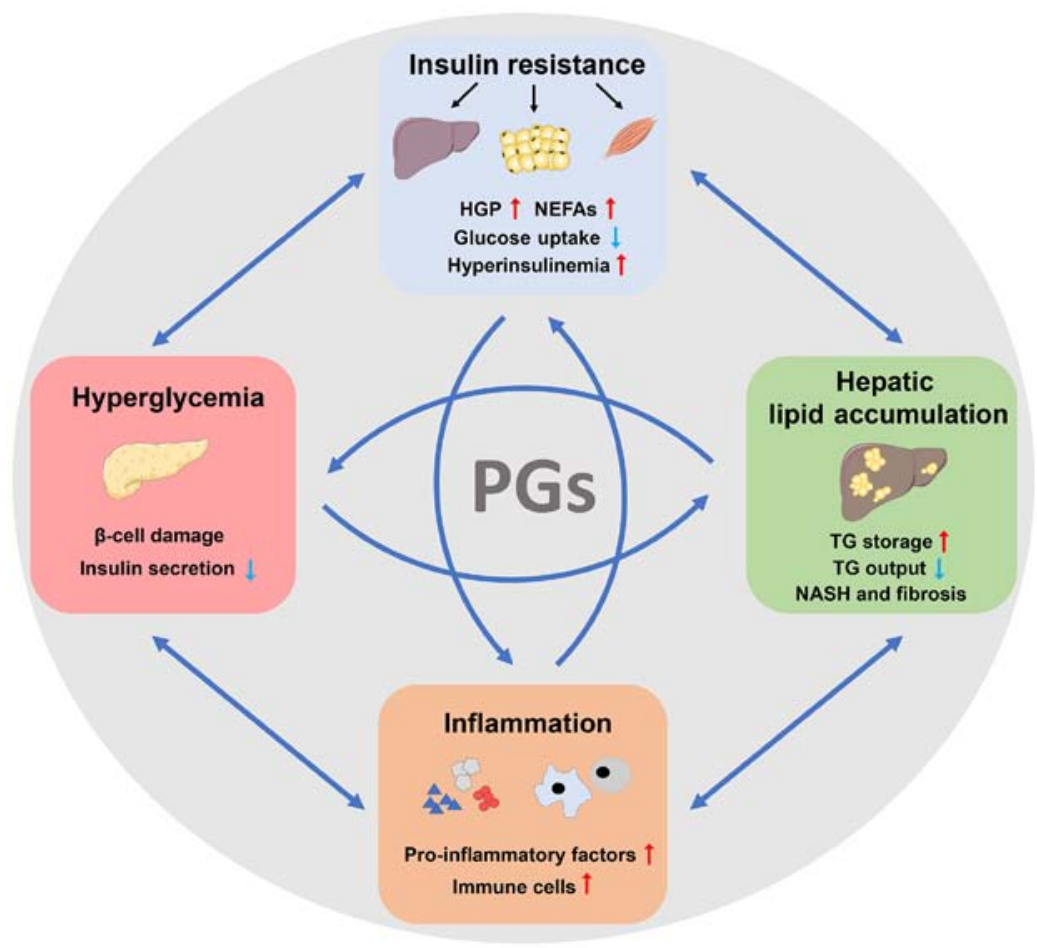

Figure 2. Schematic diagram of the 2-series PGs influence on the pathogenesis of T2DM and NAFLD. 2-Series PGs can affect four critical and highly intertwined important pathogenic mechanisms of T2DM and NAFLD, including IR, hyperglycemia, hepatic lipid accumulation and inflammation. The whole-body IR initiates or exacerbates the other three pathogenic mechanisms by increasing HGP, NEFAs, hyperinsulinemia, inflammatory mediator release (such as adipokines and cytokines) and decreasing glucose uptake. Hyperglycemia directly results from $\beta$-cell damage and decreased insulin secretion, which leads to glucotoxicity and induces both inflammation and hepatic lipid storage. Hepatic lipid accumulation is mainly caused by increased TG storage and diminished TG output. The induced lipotoxicity in the liver can accelerate hepatic or systemic inflammation. Inflammation is triggered under these metabolic stresses and responds with increased levels of inflammatory factors and immune cell recruitment in IR, $\beta$-cell damage and progression from hepatic steatosis to NASH and advanced fibrosis. T2DM, type 2 diabetes mellitus; NAFLD, non-alcoholic fatty liver disease; IR, insulin resistance; HGP, hepatic glucose production; NEFAs, non-esterified fatty acids; TG, triglyceride; NASH, non-alcoholic steatohepatitis. 


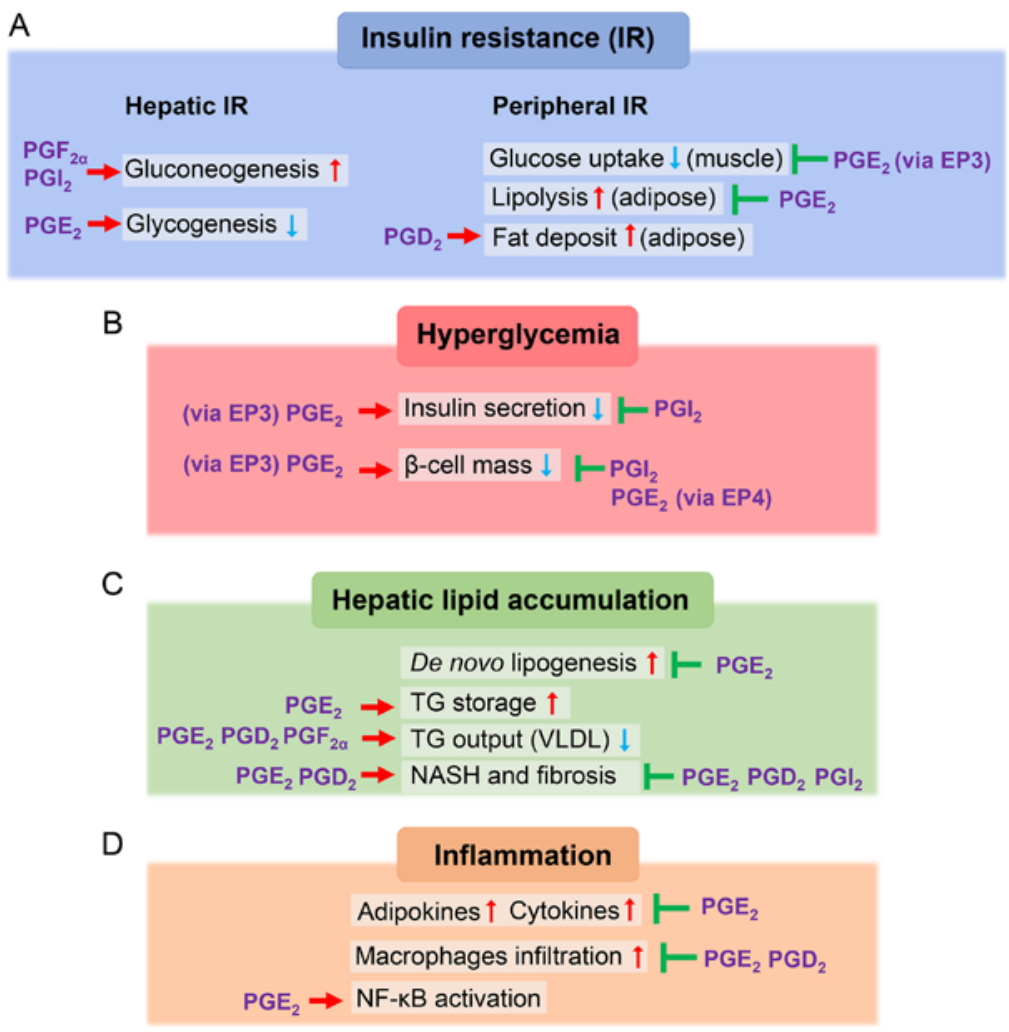

Figure 3. Role of 2-series PGs in the four pathogenesis of T2DM and NAFLD. (A) Insulin resistance. (B) Hyperglycemia. (C) Hepatic lipid accumulation. (D) Inflammation. T2DM, type 2 diabetes mellitus; NAFLD, non-alcoholic fatty liver disease.

that the $\mathrm{PGE}_{2}$-dependent feed-forward loop for NAFLD development is most likely due to the suppression of fatty acid and TG consuming pathways (fatty acid oxidation and TG export), independently of the inhibition of insulin-induced fatty acid synthesis (71).

The negative effects of PGs on insulin signaling are closely associated with hepatic glucose homeostasis (particularly gluconeogenesis). Gluconeogenic action is considerably increased under insulin resistance (73). A previous study revealed that the suppression of the hepatic $\mathrm{PGF}_{2 \alpha}-\mathrm{FP}$ axis improved insulin resistance and glucose homeostasis in $o b / o b$ mice partially via decreased hepatic gluconeogenesis (74). Under fasting conditions, PGF $_{2 \alpha}$ activates FP receptors in hepatocytes to upregulate gene expression levels of gluconeogenic rate-limiting enzymes, phosphoenolpyruvate carboxykinase (PCK1), and glucose-6-phosphatase (G6Pase) (74). The precise underlying mechanism is that FP receptor coupling with $\mathrm{G}$ protein $\mathrm{Gq}$ facilitates $\mathrm{Ca}^{2+}$ release and subsequently activates $\mathrm{Ca}^{2+} /$ calmodulin-dependent protein kinase II $\gamma$, which accelerates p38-dependent forkhead box protein $\mathrm{O} 1$ (FOXO1) nuclear translocation (74). Another study revealed that treatment with high doses of acetylsalicylic acid suppressed hepatic gluconeogenesis through the inhibition of the COX-2/PGI $/ 2$ IP axis for further improvement of diabetes (75). Hepatic gluconeogenesis was revealed to be inhibited by the downregulation of $\mathrm{PGI}_{2}$ or disruption of IP receptor in a mouse model of T2DM through the activation of the $\mathrm{G}_{\alpha s}$ /protein kinase A (PKA)/cAMP-response element binding protein pathway and inhibition of $\mathrm{G}_{\beta \gamma} / \mathrm{PI} 3 \mathrm{~K}_{-} /$protein kinase C (PKC) $-_{\xi} /$ tribbles homolog 3/Akt/FOXO1 pathway, which is involved in insulin signaling, both of which subsequently repressed the expression of G6Pase and PCK1 in hepatocytes (75). These results demonstrated that PGs can promote gluconeogenesis under insulin resistance.

Of note, PGs can also exert a protective effect on hepatic insulin signaling through the regulation of COX-2 under the stress of lipid overload, although COX-2 is widely recognized as a pro-inflammatory mediator. Hepatic COX-2 overexpression in mice fed with high-fat diet (HFD) caused a threefold increase of $\mathrm{PGE}_{2}$ and elicited preservation against hepatic insulin resistance. COX-2-dependent PG synthesis has been revealed to mediate insulin signaling by increasing the Akt and AMP-activated protein kinase phosphorylation level and decreasing the protein tyrosine phosphatase- $1 \beta$ expression level in fatty livers or hepatocytes exposed to fatty acids (76).

Peripheral insulin resistance. Insulin action in adipocytes and muscles is closely correlated with glucose and lipid metabolism in T2DM and NAFLD. The adipocyte insulin resistance can decrease intracellular TG storage and induce lipolysis, which decreases fat content and increases the release of NEFAs. Elevated circulating NEFAs can further lead to a redistribution of fat depot from adipose tissue into the liver and muscles, namely ectopic fat accumulation (65). Furthermore, adipose insulin resistance facilitates the release of adipokines (such as adiponectin, leptin and resistin) and cytokines [such as tumor necrosis factor $\alpha$ (TNF- $\alpha$ ), IL-6 and IL-1 $\beta$ ], leading to chronic low-grade inflammation in T2DM and NAFLD $(67,68)$. On the other hand, insulin resistance primarily impairs glucose uptake in muscle tissue, which results in hyperglycemia and subsequently increases glucose delivery to the liver for further hepatic lipogenesis (77). 
PGs mostly exert preventive effects against adipose insulin resistance and mediate adipogenesis in adipocytes. PGs may improve insulin sensitivity by altering inflammatory status, alleviating hepatic steatosis and overweight under obese status (78). In both subcutaneous and epididymal adipose tissues, the increased COX-2 activity enhances various PGs levels, including $\mathrm{PGE}_{2}$, which further improves the inflammatory profile including increased levels of TNF- $\alpha$, IL-33 and IL-4. This subsequently contributes to increased insulin sensitivity in adipocytes and downregulates mRNA levels of PPAR- $\gamma$ and CCAAT/enhancer-binding protein $\alpha(37,78)$. In addition, particularly under HFD treatment, mice with selective COX-2 overexpression in adipocytes resulted in a mass reduction of inguinal white adipose tissue (WAT) and decreased hepatic steatosis when compared with the littermate control (78). This finding suggested that COX-2-derived PGs may be benign mediators of type 2 immunity cues in subcutaneous WAT under deranged metabolism.

Consistent findings are shown in studies examining $\mathrm{PGE}_{2}-\mathrm{EP} 3$ signaling, which has a benefit for preventing insulin resistance and reducing fat deposit in adipose tissue. EP3 gene knockout in mice has been revealed to result in diabetes and obesity (79). The EP3 ${ }^{-/}$mice gained more weight than the $\mathrm{EP}^{+/+}$mice when fed with an HFD, and were endowed with more severe insulin resistance and adipose accumulation in the epididymis and liver. The increased fat mass and enlarged adipocyte size in epididymal WAT are associated with evoked inflammatory status, characterized by increased macrophage infiltration, upregulated TNF- $\alpha$, monocyte chemoattractant protein-1 (MCP-1) and IL-6 expression levels and necrosis. The underlying mechanism involves the EP3 receptor knockout-induced interruption of $\mathrm{PGE}_{2}$ signaling attenuating the $\mathrm{PGE}_{2}$-evoked inhibition of isoproterenol-stimulated lipolysis $(79,80)$. In addition, abnormal lipid distribution occurred alongside insulin resistance following the disruption of the $\mathrm{PGE}_{2}-\mathrm{EP} 3$ pathway when exposed to an HFD challenge. Among the group of EP3 ${ }^{-/}$mice fed with HFD, the increase of adipocyte mass and size in WAT was lower in those heavier mice, leading to a relatively increased redistribution of fat depot in liver and skeletal muscle. However, this was not observed in the group of EP3 $3^{+/+}$mice (79). This also suggested that in obese cases, $\mathrm{PGE}_{2}$-EP3 signaling may prevent excessive ectopic lipid deposition, which can subsequently cause lipid-induced hepatic and muscle insulin resistance.

Similar improvement on insulin resistance has also been observed with $\mathrm{PGD}_{2}$ action. A previous study has reported that $\mathrm{PGD}_{2}$ overproduction improved insulin sensitivity in transgenic mice overexpressing human H-PGDS (81). Furthermore, $\mathrm{PGD}_{2}$ in WAT was majorly generated by $\mathrm{H}$-PGDS in macrophages (82). $\mathrm{PGD}_{2}$ polarized macrophages from an inflammatory M1 state towards its anti-inflammatory M2 state. This polarization of macrophages was positively correlated with adipose insulin sensitivity (82). These results suggested that $\mathrm{PGD}_{2}$ may improve adipose insulin resistance by regulating macrophage polarization.

However, $\mathrm{PGD}_{2}$-mediated adipose insulin sensitivity is associated with increased body weight, adipocyte size and lipid deposition (81,83-86). Augmented H-PGDS-mediated $\mathrm{PGD}_{2}$ increase is observed in adipose tissue in obese cases and remains high even after weight loss, which indicates that
$\mathrm{PGD}_{2}$ may act as a biological driver to regain weight (83). Furthermore, L-PGDS-induced $\mathrm{PGD}_{2}$ in WAT was found to deteriorate adipose insulin resistance, increase adipose size, enhance serum cholesterol and TG levels in a study using fatty acid-binding protein 4 (aP2)-Cre/L-PGDS ${ }^{\text {flox/flox }}$ mice (84). The underlying mechanism of the $\mathrm{PGD}_{2}$-induced weight gain has been studied, and has revealed pronounced adipogenesis in WAT through the activation of the transcription and expression levels of adipogenic genes, such as PPAR- $\gamma$, aP2 and lipoprotein lipase $(81,84)$. Similarly, an in vitro study revealed that $\Delta^{12}-\mathrm{PGJ}_{2}$, a metabolite of $\mathrm{PGD}_{2}$, could accelerate adipogenesis in a PPAR- $\gamma$-dependent and -independent manner in differentiated 3T3-L1 cells (85). In addition, the $\mathrm{PGD}_{2}$-mediated lipogenic process can also be due to its function in adipose lipolysis. $\mathrm{PGD}_{2}$ increases intracellular TG levels by suppressing lipolysis through repressing cyclic adenosine monophosphate (cAMP)-PKA-hormone-sensitive lipase (HSL) axis via Gi-coupled DP2 receptor, which is dominantly expressed in adipocytes (86). This process prevents intracellular TGs in lipid droplets from hydrolytic action of HSL that may result in elevated circulating TGs. Briefly, $\mathrm{PGD}_{2}$-mediation on lipolysis is likely to improve individual metabolic disturbances including insulin resistance, dyslipidemia and hyperglycemia, despite the presence of worsening fat accumulation in peripheral tissue and weight gain (86). In combination, these results suggested that $\mathrm{PGD}_{2}$ can induce weight gain and adipose accumulation by facilitating adipogenesis and inhibiting lipolysis, which is associated with the improvement in insulin sensitivity. However, the altered fat topography and disturbed adipocyte metabolism caused by PGs may gradually predispose to the glucose intolerance in T2DM and NAFLD (87-89). The underlying mechanism is that the excessive lipid storage in adipose tissue can induce adipocyte insulin resistance and further evokes lipolysis, leading to elevated circulating NEFAs and exacerbated whole-body insulin sensitivities (87-89).

In addition to their impacts on adipose insulin resistance, PGs are also correlated with muscle insulin resistance. During the development of T2DM and NAFLD, increased delivery of NEFAs can accelerate intramyocellular lipid accumulation, which causes muscle insulin resistance. In addition, insulin-stimulated glucose transport is impaired in insulin-resistant muscles, which can happen prior to the occurrence of overt T2DM (90-92). PGs have been implicated in the translation of insulin-dependent glucose uptake into skeletal muscle (93) and, meanwhile, $\mathrm{PGE}_{2}$ enhances insulin sensitivity to increase muscle glycolysis (94). In addition, COX-2-induced $\mathrm{PGE}_{2}$ production alleviates the fatty acid-induced inflammatory process in skeletal muscle cells (95). Furthermore, intramuscular fat accumulation was observed in global deletion of EP3 receptors in diabetic mice with diet-induced obesity (79). These results suggested that the $\mathrm{PGE}_{2}$ signaling pathway may improve muscle insulin resistance. However, the intrinsic mechanism remains poorly understood.

In the aforementioned pathogenic mechanisms, 2-series PGs are most likely to aggravate hepatic insulin resistance but prevent peripheral insulin resistance. The aggravated hepatic insulin resistance eventually initiates or exacerbates hyperglycemia, hepatic lipid accumulation and inflammation, which in turn can be affected by these metabolic stresses during the 
progressive disease course. Moreover, the improved peripheral insulin resistance ameliorates blood biochemical indexes and inflammatory status, but leads to excess fat storage in muscle or adipose tissue. To date, the understanding of how 2-series PGs affect the insulin signaling pathway and the underlying molecular mechanism is lacking. Further investigations of key molecular targets will shed light onto the translational application in the treatment of T2DM and NAFLD.

\section{PGs and hyperglycemia}

Hyperglycemia is a hallmark of dysregulated glucose metabolism that contributes to the initiation and progression of T2DM and NAFLD (Fig. 2). When insulin resistance occurs, chronic hyperglycemia can induce insulin release by pancreatic $\beta$-cells, thus contributing to hyperinsulinemia (96). Under insulin resistance and hyperinsulinemia, elevated glycemia and circulating NEFAs can cause the deleterious impairment of various organs and tissues, processes that are referred to as glucotoxicity and lipotoxicity, respectively $(97,98)$. In the pancreas, glucotoxicity and lipotoxicity can account for $\beta$-cell failure and subsequent insulin secretion deficiency (97-99). In addition, hepatic gluconeogenesis can be facilitated by insulin resistance, most likely contributing to hyperglycemia by increasing the hepatic glucose output. These mechanisms collectively contribute to hyperglycemia during the development of T2DM and NAFLD.

A previous study has demonstrated the close correlation between 2-series PG action and the development of hyperglycemia (Fig. 3B). First, COX-1 and COX-2 participate in the control of glycemia (100). In a 2-week clinical trial of high-dose aspirin treatment among nine patients with T2DM, aspirin treatment was revealed to reduce fasting plasma glucose and improves insulin sensitivity in cases with diabetes (101). In addition, the increased formation of PGs and PG metabolites has been observed in T2DM, including $\mathrm{PGE}_{2}$, $\mathrm{PGI}_{2}$ in islet or blood, and 15-keto-dihydro- $\mathrm{PGF}_{2 \alpha}, 8$-iso- $\mathrm{PGF}_{2 \alpha}$ in urine (102-106). However, interference with the $\mathrm{PGE}_{2} / \mathrm{EP} 3$ signaling pathway through the blockade of the EP3 receptor in mice has been reported to predispose to systemic insulin resistance; in addition, insulin secretion also increases, finally contributing to hyperglycemia $(79,107)$. These observations imply the multifunctional involvement of 2-series PGs in the development of hyperglycemia.

$\beta$-cell failure includes $\beta$-cell dysfunction and $\beta$-cell mass deficiency, which remain the two major causes of hyperglycemic pathogenesis. $\beta$-cell dysfunction and apoptosis reduce insulin secretion and deplete $\beta$-cell mass, respectively (108). Due to their involvement in inflammation and oxidative stress signaling pathways, PGs mainly act as an initial and deteriorative pathological element for $\beta$-cell failure, leading to hyperglycemia.

Glucose-stimulated insulin secretion (GSIS) commonly occurs when $\beta$-cells are constantly exposed to high glucose stimulation (109). To a certain extent, PGs act as a potential negative modulator of GSIS. A number of studies have demonstrated that $\mathrm{PGE}_{2}$ attenuates GSIS. $\mathrm{PGE}_{2}$ is the predominant E-series PG in islets formed by COX-2, the dominant form of COX in the pancreas (110-112). COX-2 expression is significantly upregulated in pancreatic islets under hyperglycemic conditions $(113,114)$. COX-2-dependent $\mathrm{PGE}_{2}$ generation is augmented by group $\mathrm{X}$ secretory phospholipase $\mathrm{A}_{2}$ and eventually suppresses GSIS in vitro and in vivo (115). $\mathrm{PGE}_{2}$ equally inhibits both two phases of GSIS in HIT cells, which is associated with reduced cAMP accumulation mediated by pertussis toxin-sensitive $\mathrm{G}$ protein (Gi) (116). Among PGE receptors, EP3 receptor is the most abundant PGE receptor type in islets (112), which is overexpressed in islets from patients with T2DM $(117,118)$. Previous research has indicated that $\mathrm{PGE}_{2}$ coupling with EP3 receptor is highly associated with a reduction of insulin secretion in terms of $\beta$-cell dysfunction. Meng et al (118) revealed that the $\mathrm{PGE}_{2}$-stimulated gene expression of $\mathrm{PG}$ EP3 receptor subtype led to intracellular cAMP reduction, accompanied by a downregulated phosphorylation level of Akt and forkhead box 'Other' (Foxo) in HIT-T15 cells (118). Kimple et al (103) confirmed that this active $\mathrm{PGE}_{2} / \mathrm{EP} 3$ receptor pathway in islets depended on coupling to G-proteins of the Gi subfamily in vivo. In addition, EP3 receptor agonists can antagonize glucagon-like peptide-1 (GLP-1) signaling, leading to reduced cAMP production and attenuated GSIS (103). Hence, since GLP-1 treatment is not effective in all patients with T2DM (119), as a non-competitive antagonist of GLP-1 receptor, EP3 receptor may be a potent target for improving the GLP-1 effect in anti-diabetic therapeutics $(103,120)$. Another observation revealed that $\mathrm{PGE}_{2}$ presents an impotent influence on GSIS suppression in rat islets exposed to epinephrine-induced glucose overload (121). Under hyperglycemic states, crosstalk between PGs and other inflammatory factors has a profound effect on glycemic control. Systemic inflammatory responses are upregulated in T2DM individuals (122), characterized by elevated levels of lipid molecules, including PGs and cytokines such as TNF- $\alpha$ (123), IL-1 $\beta$ (124), IL-6 (125) and IL-8 (126), in correspondence with the decline of their natural antibodies (127). In PG signaling, COX-2 is involved in IL- $1 \beta$-induced auto-stimulation in islets (111). The COX-2 expression and activity are upregulated by IL-1 $\beta$-induced $\mathrm{NF}-\kappa \mathrm{B}$ activation, resulting in a negative effect on GSIS caused by increased $\mathrm{PGE}_{2}$ via EP3 receptor (112). Recently, the IL-1 $\beta / \mathrm{COX}-2 / \mathrm{PGE}_{2}$ pathway loop has been revealed as the underlying mechanism for the onset and progression of diabetes, which leads to $\beta$-cell inflammatory impairments by downregulating the expression of $\beta$-cell functional genes pancreatic and duodenal homeobox 1, NK6 homeobox 1 and MAF bZIP transcription factor A (124). As previously mentioned, $\mathrm{PGE}_{2}$ can impact GSIS through different receptors and also by interacting with inflammatory reaction in hyperglycemia.

Considering other $\mathrm{PGs}, \mathrm{PGI}_{2}$ also plays a pivotal role in the protection of $\beta$-cell function and survival via IP receptor signaling. The IP receptor/cAMP/PKA/nephrin signaling pathway participates in the preservation of $\beta$-cell function and mass in vitro and in vivo. IP receptor agonism augments insulin release in pancreatic $\beta$-cells and promotes the viability of MIN6 $\beta$-cells as a consequence of intracellular cAMP increase, PKA activation and subsequent nephrin phosphorylation (104). Consistently, a study revealed that selexipag, a prodrug form of IP receptor agonist, exerted a similar improvement on GSIS and $\beta$-cell mass in diabetic mice (104).

Deficient $\beta$-cell mass is recognized as another essential event that results in elevated glycemia in T2DM 
progression $(128,129)$. Apart from delaying the GSIS process, $\mathrm{COX}-2 / \mathrm{PGE}_{2}$ signaling also plays a role in the regulation of $\beta$-cell proliferation and apoptosis. In a model of transgenic mice overexpressing COX-2 and microsomal prostaglandin $\mathrm{E}$ synthase 1 (mPGES-1), increased $\mathrm{PGE}_{2}$ appeared to be associated with a significant reduction in the number of $\beta$-cells and further caused severe hyperglycemia (130). A different study concluded that the blockade of EP3 receptor and activation of EP4 receptor enhanced human $\beta$-cell proliferation and survival ex vivo, suggesting a reciprocal effect of different EP receptors on the mediation of $\beta$-cell failure in T2DM (117). Furthermore, an EP3 receptor antagonist improved $\beta$-cell proliferation partly by enhancing phospholipase $\mathrm{C}-\gamma 1$ activity in young mouse islets rather than in old ones, while the EP4 receptor was activated to exert the same protective effect in human $\beta$-cells only with combination of EP3 inhibition. In terms of promotion of $\beta$-cell survival, forkhead box protein M1, a critical $\beta$-cell proliferation factor, is upregulated by EP3 antagonist and EP4 agonist in islets from obese T2DM individuals (117). However, EP4 has further been revealed to be involved in PKA signaling activation through $\mathrm{a}_{\mathrm{s}}$-coupled mechanism in the survival of mouse $\beta$-cells, which is proposed to facilitate the phosphorylation of eukaryotic initiation factor $4 \mathrm{E}$ and PKC- $\varepsilon$ in a putative downstream mechanism (117). In addition, $\alpha$-subunit of the heterotrimeric $\mathrm{G}_{\mathrm{z}}$ protein $\left(\mathrm{G} \alpha_{\mathrm{v}}\right)$, a member of the $\mathrm{G} \alpha_{\mathrm{i}}$ family, may couple to EP3 in pancreatic $\beta$-cells (131). The global deletion of $\mathrm{G}_{\mathrm{z}}$ can block the $\mathrm{PGE}_{2} / \mathrm{EP} 3$ pathway, which subsequently results in a robust increase in $\beta$-cell mass and augments GSIS by cAMP upregulation in mice with both insulin resistance and glucose intolerance (120). In addition, EP3 receptor knockout in HFD-fed mice was revealed to promote $\beta$-cell proliferation (79), which is consistent with the aforementioned $\mathrm{G} \alpha_{\mathrm{z}}$-null data. Notably, in human islets from patients with T2DM and MIN6 $\beta$-cells, palmitate can upregulate the expression levels of COX-2 and EP3 receptor, which initiates $\beta$-cell apoptosis through the $\mathrm{COX}-2 / \mathrm{PGE}_{2} / \mathrm{EP} 3$ pathway (132). These results demonstrated that the $\mathrm{PGE}_{2}$ pathway can inhibit proliferation and induce apoptosis in $\beta$-cells exposed to glucotoxicity and lipotoxicity.

Based on the available studies of 2-series PG-mediated glycemic control, the $\mathrm{PGE}_{2}$ and $\mathrm{PGI}_{2}$ signaling pathways are considered crucial pathogenic contributors in the regulation of $\beta$-cell function and proliferation, although $\mathrm{PGE}_{2}$ exerts completely different effects on hyperglycemia through EP3 and EP4 receptors. Furthermore, PGs, mainly $\mathrm{PGF}_{2 \alpha}$ and $\mathrm{PGI}_{2}$, can enhance circulating blood glucose by accelerating gluconeogenesis and glycogenolysis through insulin signaling (described in Hepatic insulin resistance). Enhanced glycemia can be predisposed to excessive glucose accumulation in the liver which can be converted to lipid formation. Therefore, targeting the 2 -series PG pathway can be a promising therapeutic strategy for the protection and recovery of both $\beta$-cell and liver abnormalities.

\section{PGs and hepatic lipid accumulation}

Elevated circulating lipid contents (such as cholesterol, TG and NEFAs) are a characteristic of T2DM and NAFLD (Fig. 2) (133-135). Lipotoxicity alone or in combination with glucotoxicity is highly associated with the impairment of insulin sensitivity in various organs. Previous clinical studies have revealed that lipid infusion contributes to hepatic insulin resistance (136). In addition, the accumulation of hepatic lipid contents, particularly TGs, is an initiation of liver steatosis. Liver steatosis is the first hit in the progression of NAFLD, whose onset is due to insulin resistance $(19,137)$. The direct contributors to excess lipid storage in the liver include increased circulating NEFAs, accelerated de novo lipogenesis, overloaded dietary fat and inadequate lipid oxidation $(64,65,134,138)$. In turn, hepatic steatosis induces subacute intrahepatic inflammation through the NF- $\kappa \mathrm{B}$ pathway as a pathogenic mechanism for exacerbated hepatic and systematic insulin resistance both in NAFLD and T2DM $(19,139)$.

PGs markedly contribute to the dysregulation of the lipid metabolism in hepatic lipid accumulation (Fig. $3 \mathrm{C}$ ). $\mathrm{PGE}_{2}$ acts synergistically with insulin in the pathogenesis of hepatic steatosis, but their roles remain discordant and controversial. $\mathrm{PGE}_{2}$ decreases the activity of lipogenic enzymes in primary hepatocytes in vitro through sustained ERK1/2 activation, thereby attenuating insulin-dependent phosphorylation of Akt kinase. This finally abrogates insulin signaling and further alleviates SREBP-1c pathway in hepatic de novo lipogenesis (140). Furthermore, short-term blockade of $\mathrm{PGE}_{2}$ signaling by EP3 antagonist in mice with diet-induced obesity caused a significant reduction of TG content in skeletal muscle and slightly increased hepatic TGs (107). As a result, it can be hypothesized that $\mathrm{PGE}_{2}$ elicits preservation against hepatic steatosis. However, other observations vary from this hypothesis. A previous study has indicated that extracellular $\mathrm{PGD}_{2}, \mathrm{PGE}_{2}$ and $\mathrm{PGF}_{2 \alpha}$ diminish the secretion of very low-density lipoprotein (VLDL)-apolipoprotein B (apoB) to promote steatosis in primary hepatocytes (141). The reduction of VLDL-apoB is correlated with decreased TG transportation and impaired cellular TG recycling, which finally results in a reduced TG output. In addition, only $\mathrm{PGE}_{2}$ can completely antagonize the IL-6-induced secretion of VLDL-apoB in hepatocytes (141). Furthermore, $\mathrm{PGE}_{2}$ acts synergistically with insulin and enhances the incorporation of glucose into TGs in hepatocytes. $\mathrm{PGE}_{2}$ and insulin synergistically inhibit lipolysis, mitochondrial $\beta$-oxidation and VLDL synthesis, which are mediated by $\mathrm{PGE}_{2}$-dependent suppression of adipose TG lipase, carnitine palmitoyltransferase- 1 and apoB-mediated lipidation, respectively (140). Moreover, apoB and microsomal transfer protein are downregulated by PPAR- $\gamma$-coactivator- $1 \alpha$ and PCK1 in insulin-dependent and $\mathrm{PGE}_{2}$-dependent manners. In combination, these events contribute to a reduced $\mathrm{TG}$ breakdown and increased fat droplets in hepatocytes (140). In terms of NAFLD development in vivo, under HFD feeding, increased COX-2 activity and $\mathrm{PGE}_{2}$ concentration also results in hepatic steatosis in mice mostly through NF- $\kappa \mathrm{B}$ activation and lipid peroxidation enhancement. An aggravation of insulin resistance also appears with increased levels of serum alanine aminotransferase and total hepatic fatty acids (142). Another putative mechanism of hepatic steatosis formation involves CD36-mediated PG levels in the liver. Although the expression level of CD36 was 5-fold higher in hepatic steatosis liver than in normal liver, the global deletion of CD36 in $o b / o b$ mice aggravated hepatic lipid accumulation by significantly suppressing the outputs of VLDL, apoB and TGs by increasing hepatic $\mathrm{PGD}_{2}, \mathrm{PGE}_{2}$ and $\mathrm{PGF}_{2 \alpha}$ (143). Based on 
these experiments, $\mathrm{PGs}$ including $\mathrm{PGD}_{2}, \mathrm{PGE}_{2}$ and $\mathrm{PGF}_{2 \alpha}$ may accelerate the initiation and progression of hepatic steatosis.

Conversely, beraprost sodium, a $\mathrm{PGI}_{2}$ analog, was revealed to be effective in ameliorating metabolic disturbances in obesity and obesity-associated T2DM. Various manifestations were revealed to be improved by $\mathrm{PGI}_{2}$ analog treatment, including hepatic steatosis, adipose hypertrophy, glucose intolerance, hyperglycemia, hyperinsulinemia and other related complications, such as pancreatic fibrosis and nephropathy (144). This suggests that $\mathrm{PGI}_{2}$ can be beneficial to the treatment of obesity-associated T2DM and NAFLD.

Since the mediation of PGs on hepatic lipid accumulation is ambiguous, the precise mechanism requires further study. Considering the findings of the aforementioned studies, it can be hypothesized that various PGs $\left(\mathrm{PGD}_{2}, \mathrm{PGE}_{2}\right.$ and $\mathrm{PGF}_{2 \alpha}$ ) promote hepatic lipid accumulation, mostly through facilitating TG storage and inhibiting TG output by repressing lipolysis, fatty acid oxidation and VLDL synthesis. In addition, under insulin resistance, PGs can increase de novo lipogenesis and promote the development of hepatic steatosis. As hepatic lipid accumulation is the initial step of NAFLD as well as a risk factor for T2DM, the inhibition of the 2-series $P G$ pathway may be a potential option for treating NAFLD.

\section{PGs and inflammation}

Systemic chronic inflammation is a health-damaging phenotype that plays a central role in multiple metabolic syndromes, including T2DM and NAFLD (Fig. 2) (145,146). 2-Series PGs have multifunctional effects on the promotion and resolution of inflammation following the occurrence of insulin resistance, $\beta$-cell failure and hepatic steatosis (Fig. 3D) $(37,71,78,79,82,112,142)$. PGs, TNF- $\alpha$, IL-1 $\beta$ and IL-6 have been recognized as the major inflammatory mediators in T2DM and NAFLD (102,145-148). There are multifaceted interactions between PGs and other inflammatory molecules or cells in the pathogenic mechanisms of T2DM and NAFLD. As aforementioned, COX-2-derived PGs disrupt insulin signaling by activating the STAT3/SOCS3 signaling pathway in the liver or interacting with TNF- $\alpha$ and ILs in WAT $(37,71,78)$, whereas, in obesity, $\mathrm{PGD}_{2}$ and $\mathrm{PGE}_{2}$ mediate macrophage polarization and infiltration with downregulated TNF- $\alpha$, MCP-1 and IL-6 in WAT, leading to an improvement in peripheral insulin resistance $(79,82)$. In turn, when peripheral insulin resistance occurs, adipokines and cytokines are released from dysfunctional adipose tissues and subsequently induce inflammation, which is associated with $\beta$-cell failure and hepatic steatosis. COX-2-derived $\mathrm{PGE}_{2}$ contributes to $\beta$-cell dysfunction in GSIS via IL-1 $\beta$-induced NF- $\kappa B$ activation (112), and hepatic lipid accumulation via NF- $\kappa \mathrm{B}$ activation (142). NF- $\kappa \mathrm{B}-$ mediated inflammation is important in the pathogenesis of T2DM and NAFLD. PGs may be involved in inflammatory processes mostly through NF- $\kappa$ B pathway activation with or without coaction with other inflammatory factors. The inhibitor $\kappa \mathrm{B}$ kinase $\beta$ (IKK- $\beta$ ) $/ \mathrm{NF}-\kappa \mathrm{B}$ pathway plays a critical role in chronic hepatic inflammation, leading to insulin resistance and steatohepatitis, in which TNF- $\alpha$ and IL-1 $\beta$ are also involved $(19,139)$.

Hepatic inflammation is a landmark in the development of $\mathrm{NASH}$, which is also triggered by progressed insulin resistance and other injurious stimuli, such as glucotoxicity and lipotoxicity (149-152). Progressively, NASH-related hepatic fibrosis and cirrhosis become long-term manifestations of NAFLD. Hepatic fibrosis is characterized by high-density extracellular matrix protein deposition (153). Both NASH and liver fibrosis can be exacerbated in NAFLD with comorbidity of T2DM (154,155). T2DM-promoted NASH is attributed to peripheral insulin resistance, intrahepatic lipotoxicity and M1 macrophage recruitment in adipose tissue (156-158). The activated M1 macrophages secrete pro-inflammatory cytokines, including MCP-1, TNF- $\alpha$ and IL- $1 \beta$, which induce systemic inflammation. These cytokines are further delivered to the liver and cause steatohepatitis (159). Therefore, insulin resistance, hyperglycemia, hyperinsulinemia and hyperlipidemia are key factors for pro-inflammatory status in hepatic inflammation, in which PGs are involved as inflammatory mediators. In addition, the upregulation of transforming growth factor- $\beta$ (TGF- $\beta$ ) and connective tissue growth factor in T2DM can lead to NAFLD-related fibrosis progression $(160,161)$.

PGs are correlated with the progression from hepatic steatosis to NASH. The upregulated expression of COX-2 and mPGES-1, the key enzymes of $\mathrm{PGE}_{2}$ synthesis, is closely associated with NASH activity score in human liver from patients with NASH (162). Lipidomics profiling was performed in a clinical cohort that attempted to describe the hepatic inflammatory characteristic of NASH. As a result, the plasma $\mathrm{PGE}_{2}$ level was revealed to be elevated only in patients with $\mathrm{NASH}$, while the level of 13,14-dihydro-15-keto- $\mathrm{PGD}_{2}$, a metabolite degraded from $\mathrm{PGD}_{2}$, was found to be remarkably higher in the NASH group, compared with the simple steatosis or control groups (163). As a consequence, it is reasonable to suggest that PGs, particularly $\mathrm{PGE}_{2}$, may aggravate the course of NAFLD.

However, there are some discrepancies in the impact of PGs and COX-2 activity on the development of NASH under dietary nutritious stress. An in vivo study revealed that hepatocyte-specific COX-2 transgenic mice (hCOX-2-Tg) with an increased level of $\mathrm{PGE}_{2}$ improved intrahepatic steatosis, ballooning and inflammation (164). This was partially achieved by decreasing the plasma levels of pro-inflammatory cytokines (such as IL-1 $\beta$, IL-6, TNF- $\alpha$ and MCP-1), and inhibiting macrophage recruitment and infiltration in steatohepatitis liver induced by a methionine- and choline-deficient diet (MCDD) (164). In addition, there are ameliorations of augmented oxidative stress and apoptosis in liver samples with NASH (164). Similarly, under a NASH diet, hepatic $\mathrm{PGE}_{2}$ production derived from mPGES-1 is increased to potently inhibit monocyte-derived macrophage infiltration, which is associated with $\mathrm{PGE}_{2}$-induced suppression of TNF- $\alpha$-triggered responses in hepatocytes. These responses consist of pro-inflammatory cytokine IL-1 $\beta$ production and hepatocyte apoptosis (162). These results suggest a combined action of PGs and other inflammatory factors in NASH development. Furthermore, the blockade of L-PGDS in $\mathrm{PGD}_{2}$ signaling rapidly accelerates non-alcoholic simple steatosis to severe steatohepatitis in nutrition overload or normal conditions (165). This progression to NASH is also accompanied by enhanced lipogenic gene expression (such as SREBP-1c and liver $\mathrm{X}$ receptor $\alpha$ ) and deranged metabolic features, including progressed insulin resistance and increased fasting glucose, insulin and lipid levels in the blood (165). With 
regards to the $\mathrm{PGI}_{2} / \mathrm{IP}$ pathway, under MCDD conditions, IP-receptor-knockout (IP-KO) mice had accelerated progression to steatohepatitis, with greater iron deposition due to marked oxidative stress. PGI $_{2}$-IP signaling prevents the development of NASH in anti-inflammatory response, as evidenced by the suppressed expression of MCP-1 and TNF- $\alpha$ in lipopolysaccharide-stimulated Kupffer cells in vitro. Consistently, the Kupffer cell-induced expression levels of MCP-1 and TNF- $\alpha$ were progressively increased in IP-KO mice, and the oxidative stress-induced hepatic iron deposition was reduced in the MCDD-induced steatohepatitis liver, suggesting that $\mathrm{PGI}_{2}$ signaling inhibits inflammation and influences the antioxidant reaction in NASH (166). Thus, PG appears to play a protective role against hepatic steatohepatitis, most likely under disturbed metabolism in NAFLD and T2DM progression.

The key mechanisms of hepatic fibrosis include a disbalance between fibrogenesis and fibrinolysis and the activation of hepatic stellate cells (HSCs) and Kupffer cells in response to various stimuli $(167,168)$. Numerous studies have revealed that PGs facilitate the development of hepatic steatosis, steatohepatitis and fibrosis (169-171). In a prospective cohort research of 361 patients with NAFLD, daily aspirin use induced less severity of histologic characteristics of NAFLD and significantly decreased the risk of fibrosis initiation and progression in a duration-dependent manner, when compared with the non-regular use of aspirin (172). It was further suggested that the antifibrotic effect of long-term aspirin treatment is attributed to its involvement in inhibiting NF- $\kappa \mathrm{B}$ and IKK- $\beta$ signaling (173). Furthermore, plasma bioactive lipids, such as $\mathrm{PGE}_{2}$ and $\mathrm{PGI}_{2}$, have been regarded as useful markers for prognosis in liver cirrhosis (174). In accordance with clinical evidence, the upregulation of COX-2 was positively correlated with fibrosis formation in liver from a carbon tetrachloride $\left(\mathrm{CCl}_{4}\right)$-induced fibrotic mouse model (175). Conversely, it was revealed that $\mathrm{COX}$-2-derived $\mathrm{PGE}_{2}$ could suppress fibrogenesis and NASH progression (176,177). In hCOX-2 Tg mice with diet-induced $\mathrm{NASH}, \mathrm{PGE}_{2}$ attenuated $\mathrm{CCl}_{4}$-induced liver fibrosis by decreasing the activation and proliferation of HSCs and increasing apoptosis by suppressing microRNA (miR)-23a and miR-28a expression $(164,178)$. In addition, COX-2-derived $\mathrm{PGE}_{2}$ was revealed to suppress collagen synthesis through the downregulation of collagen type I $\alpha 1, \alpha$ smooth muscle actin and collagen binding protein-1 in HSCs under TGF- $\beta 1$-induced conditions $(178,179)$. These results demonstrated that the COX-2/PGE 2 pathway prevents the development of liver fibrosis through growth-suppressive and pro-apoptotic effects on HSCs.

To sum up, during the progression of T2DM and NAFLD, PGs may primarily act by interacting with other inflammatory factors, as well as mediating the NF- $\mathrm{KB}$ signaling pathway, which plays an important role in the chronic inflammation caused by glucotoxicity and lipotoxicity in a variety of organs. PGs can serve as pro-inflammatory mediators in the impairment of insulin sensitivity, glycemia and hepatic lipid metabolism. However, $\mathrm{PGD}_{2}, \mathrm{PGE}_{2}$ and $\mathrm{PGI}_{2}$ also exert anti-inflammatory effects and improve peripheral insulin resistance, NASH and related fibrosis. Due to the complex action of PGs in the inflammatory process, the use of COX inhibitors in T2DM and NAFLD treatment should be given more consideration, and further explorations are highly warranted.

\section{Conclusion and future perspectives}

The comorbidity of T2DM and NAFLD is well recognized and has become an area of increased investigation over past decades. Nowadays, considerable evidence has highlighted the roles of 2-series PGs in the pathogenesis of T2DM and NAFLD. 2-Series PGs are important lipid molecules that are widely distributed in various organs. These exert multifunctional effects on the four highly intertwined pathogeneses of T2DM and NAFLD, including insulin resistance, hyperglycemia, hepatic lipid accumulation and chronic inflammation. PGs potently mediate insulin resistance, which subsequently induces pathological alterations including hyperinsulinemia, hyperglycemia, dyslipidemia and ectopic lipid accumulation. In addition, PGs can directly impact hyperglycemia by decreasing insulin secretion, pancreatic $\beta$-cell proliferation and increasing gluconeogenesis. In addition, PGs contribute to hepatic lipid accumulation by enhancing hepatic lipogenesis and decreasing TG output. Moreover, PGs distinctly establish a close interaction with inflammatory processes in the progression of T2DM and NAFLD.

Most 2-series PGs exert negative effects on the progression of T2DM and NAFLD. Therefore, the application of COX inhibitors such as aspirin and celecoxib beyond their conventional use on vascular diseases, rheumatoid arthritis and pain is emerging as a promising option for T2DM and NAFLD treatment. However, certain aspects of the application of PG pathways should be considered. First, some PGs are beneficial to the prevention of T2DM and NAFLD development to a certain extent, suggesting that the clinical use of COX inhibitors requires careful consideration and highlighting the potential therapeutic use of PGs and their derivates in the prevention and control of T2DM and NAFLD. Secondly, since the existing NSAIDs and COXIBs are associated with several side effects, it is meaningful to perform molecular modification of these drugs and develop new treatment strategies, to aim to accurately modulate the PG pathway in related organs such as the pancreas, liver and adipose tissues. Overall, due to the important role of 2-series PGs in T2DM and NAFLD, additional studies associated with the molecular mechanisms of PGs in the pathogenesis of T2DM and NAFLD are highly warranted. These studies will provide new and more precise therapeutic strategies based on targeting PG pathways in the treatment of these two diseases.

\section{Acknowledgements}

The authors would like to thank Professor Lexun Wang from the Institute of Chinese Medicine Sciences, Guangdong Pharmaceutical University, Guangzhou, China for editing and reviewing our manuscript.

\section{Funding}

This work was supported by the National Key R\&D plan 'Research on modernization of traditional Chinese medicine' (grant no. 2018YFC1704200), the Major Basic And Applied Basic Research Projects of Guangdong Province of China (grant no. 2019B030302005), the Basic and Applied Basic Research fund of Guangdong Province (grant no. 2021A1515012553), the Innovative Strong School 
Project of Guangdong Pharmaceutical University (grant no. 2018KQNCX130), the Basic and Applied Basic Research Fund of Guangdong Province (grant no. 2019A1515110123), and the Medical Science and Technology Research Fund of Guangdong Province (grant no. A2019531).

\section{Availability of data and materials}

Not applicable.

\section{Authors' contributions}

JG, WW and XZ conceived the study. WW and XZ wrote and prepared the original manuscript. JG and WW contributed to the review of the manuscript. JG and WW were responsible for the funding acquisition. All authors read the final manuscript and agree to be accountable for the content of the work.

\section{Ethics approval and consent to participate}

Not applicable.

\section{Patient consent for publication}

Not applicable.

\section{Competing interests}

The authors declare that they have no competing interests.

\section{References}

1. International Diabetes Federation(IDF): IDF diabetes atlas, 9th edition. IDF, Brussels, 2019.

2. Younossi ZM, Koenig AB, Abdelatif D, Fazel Y, Henry L and Wymer M: Global epidemiology of nonalcoholic fatty liver disease-meta-analytic assessment of prevalence, incidence, and outcomes. Hepatology 64: 73-84, 2016.

3. Chatterjee S, Khunti K and Davies MJ: Type 2 diabetes. Lancet 389: 2239-2251, 2017.

4. Younossi Z, Anstee QM, Marietti M, Hardy T, Henry L, Eslam M, George J and Bugianesi E: Global burden of NAFLD and NASH: Trends, predictions, risk factors and prevention. Nat Rev Gastroenterol Hepatol 15: 11-20, 2018.

5. Zhou F, Zhou J, Wang W, Zhang XJ, Ji YX, Zhang P, She ZG, Zhu L, Cai J and $\mathrm{Li} \mathrm{H}$ : Unexpected rapid increase in the burden of NAFLD in China from 2008 to 2018: A systematic review and meta-analysis. Hepatology 70: 1119-1133, 2019.

6. Younossi ZM, Golabi P, de Avila L, Paik JM, Srishord M, Fukui N, Qiu Y, Burns L, Afendy A and Nader F: The global epidemiology of NAFLD and NASH in patients with type 2 diabetes: A systematic review and meta-analysis. J Hepatol 71: 793-801, 2019.

7. Sung KC, Jeong WS, Wild SH and Byrne CD: Combined influence of insulin resistance, overweight/obesity, and fatty liver as risk factors for type 2 diabetes. Diabetes Care 35: 717-722, 2012

8. Wild SH, Morling JR, McAllister DA, Kerssens J, Fischbacher C, Parkes J, Roderick PJ, Sattar N and Byrne CD; Scottish and Southampton Diabetes and Liver Disease Group; Scottish Diabetes Research Network Epidemiology Group: Type 2 diabetes and risk of hospital admission or death for chronic liver diseases. J Hepatol 64: 1358-1364, 2016.

9. Leite NC, Villela-Nogueira CA, Pannain VL, Bottino AC, Rezende GF, Cardoso CR and Salles GF: Histopathological stages of nonalcoholic fatty liver disease in type 2 diabetes: Prevalences and correlated factors. Liver Int 31: 700-706, 2011

10. Prashanth M, Ganesh HK, Vima MV, John M, Bandgar T, Joshi SR, Shah SR, Rathi PM, Joshi AS, Thakkar H, et al: Prevalence of nonalcoholic fatty liver disease in patients with type 2 diabetes mellitus. J Assoc Physicians India 57: 205-210, 2009.
11. Dam-Larsen S, Franzmann M, Andersen IB, Christoffersen P, Jensen LB, Sørensen TI, Becker U and Bendtsen F: Long term prognosis of fatty liver: Risk of chronic liver disease and death. Gut 53: 750-755, 2004

12. Ratziu V, Bonyhay L, Di Martino V, Charlotte F, Cavallaro L, Sayegh-Tainturier MH, Giral P, Grimaldi A, Opolon P and Poynard T: Survival, liver failure, and hepatocellular carcinoma in obesity-related cryptogenic cirrhosis. Hepatology 35 : 1485-1493, 2002.

13. Ekstedt M, Franzén LE, Mathiesen UL, Thorelius L, Holmqvist M, Bodemar $\mathrm{G}$ and Kechagias S: Long-term follow-up of patients with NAFLD and elevated liver enzymes. Hepatology 44: 865-873, 2006.

14. Rafiq N, Bai C, Fang Y, Srishord M, McCullough A, Gramlich T and Younossi ZM: Long-term follow-up of patients with nonalcoholic fatty liver. Clin Gastroenterol Hepatol 7: 234-238, 2009.

15. Targher G, Bertolini L, Padovani R, Rodella S, Tessari R, Zenari L, Day C and Arcaro G: Prevalence of nonalcoholic fatty liver disease and its association with cardiovascular disease among type 2 diabetic patients. Diabetes Care 30: 1212-1218, 2007.

16. Ryysy L, Häkkinen AM, Goto T, Vehkavaara S, Westerbacka J, Halavaara $\mathbf{J}$ and Yki-Järvinen H: Hepatic fat content and insulin action on free fatty acids and glucose metabolism rather than insulin absorption are associated with insulin requirements during insulin therapy in type 2 diabetic patients. Diabetes 49: 749-758, 2000.

17. Lomonaco R, Bril F, Portillo-Sanchez P, Ortiz-Lopez C, Orsak B, Biernacki D, Lo M, Suman A, Weber MH and Cusi K: Metabolic impact of nonalcoholic steatohepatitis in obese patients with type 2 diabetes. Diabetes Care 39: 632-638, 2016.

18. Marchesini G, Brizi M, Bianchi G, Tomassetti S, Bugianesi E, Lenzi M, McCullough AJ, Natale S, Forlani G and Melchionda N: Nonalcoholic fatty liver disease: A feature of the metabolic syndrome. Diabetes 50: 1844-1850, 2001.

19. Cai D, Yuan M, Frantz DF, Melendez PA, Hansen L, Lee J and Shoelson SE: Local and systemic insulin resistance resulting from hepatic activation of IKK-beta and NF-kappaB. Nat Med 11: 183-190, 2005.

20. Sun G, Jackson CV, Zimmerman K, Zhang LK, Finnearty CM, Sandusky GE, Zhang G, Peterson RG and Wang YJ: The FATZO mouse, a next generation model of type 2 diabetes, develops NAFLD and NASH when fed a Western diet supplemented with fructose. BMC Gastroenterol 19: 41, 2019.

21. Garcia-Jaramillo M, Spooner MH, Löhr CV, Wong CP, Zhang W and Jump DB: Lipidomic and transcriptomic analysis of western diet-induced nonalcoholic steatohepatitis (NASH) in female Ldlr-/-mice. PLoS One 14: e0214387, 2019.

22. Verboven M, Deluyker D, Ferferieva V, Lambrichts I, Hansen D, Eijnde $\mathrm{BO}$ and Bito V: Western diet given to healthy rats mimics the human phenotype of diabetic cardiomyopathy. J Nutr Biochem 61: 140-146, 2018.

23. Hernandez-Rodas MC, Valenzuela R and Videla LA: Relevant aspects of nutritional and dietary interventions in non-alcoholic fatty liver disease. Int J Mol Sci 16: 25168-25198, 2015.

24. Valenzuela R and Videla LA: The importance of the long-chain polyunsaturated fatty acid $n-6 / n-3$ ratio in development of non-alcoholic fatty liver associated with obesity. Food Funct 2: 644-648, 2011.

25. Taha AY, Cheon Y, Faurot KF, Macintosh B, Majchrzak-Hong SF, Mann JD, Hibbeln JR, Ringel A and Ramsden CE: Dietary omega- 6 fatty acid lowering increases bioavailability of omega-3 polyunsaturated fatty acids in human plasma lipid pools. Prostaglandins Leukot Essent Fatty Acids 90: 151-157, 2014.

26. Wood KE, Lau A, Mantzioris E, Gibson RA, Ramsden CE and Muhlhausler BS: A low omega- 6 polyunsaturated fatty acid (n-6 PUFA) diet increases omega-3 (n-3) long chain PUFA status in plasma phospholipids in humans. Prostaglandins Leukot Essent Fatty Acids 90: 133-138, 2014.

27. Xia F, He C, Ren M, Xu FG and Wan JB: Quantitative profiling of eicosanoids derived from n- 6 and n-3 polyunsaturated fatty acids by twin derivatization strategy combined with LC-MS/MS in patients with type 2 diabetes mellitus. Anal Chim Acta 1120: 24-35, 2020.

28. Li N, Yue H, Jia M, Liu W, Qiu B, Hou H, Huang F and Xu T: Effect of low-ratio n-6/n-3 PUFA on blood glucose: A meta-analysis. Food Funct 10: 4557-4565, 2019.

29. Liu HQ, Qiu Y, Mu Y, Zhang XJ, Liu L, Hou XH, Zhang L, $\mathrm{Xu}$ XN, Ji AL, Cao R, et al: A high ratio of dietary $n-3 / n-6$ polyunsaturated fatty acids improves obesity-linked inflammation and insulin resistance through suppressing activation of TLR4 in SD rats. Nutr Res 33: 849-858, 2013. 
30. Shrestha N, Cuffe JSM, Holland OJ, Perkins AV, McAinch AJ and Hryciw DH: Linoleic acid increases prostaglandin E2 release and reduces mitochondrial respiration and cell viability in human trophoblast-like cells. Cell Physiol Biochem 52: 94-108, 2019.

31. Kliewer SA, Lenhard JM, Willson TM, Patel I, Morris DC and Lehmann JM: A prostaglandin J2 metabolite binds peroxisome proliferator-activated receptor gamma and promotes adipocyte differentiation. Cell 83: 813-819, 1995.

32. Hennig B, Toborek M, Joshi-Barve S, Barger SW, Barve S, Mattson MP and McClain CJ: Linoleic acid activates nuclear transcription factor-kappa B (NF-kappa B) and induces NF-kappa B-dependent transcription in cultured endothelial cells. Am J Clin Nutr 63: 322-328, 1996.

33. Seo MJ and Oh DK: Prostaglandin synthases: Molecular characterization and involvement in prostaglandin biosynthesis. Prog Lipid Res 66: 50-68, 2017.

34. Schaid MD, Zhu Y, Richardson NE, Patibandla C, Ong IM, Fenske RJ, Neuman JC, Guthery E, Reuter A, Sandhu HK, et al Systemic metabolic alterations correlate with islet-level prostaglandin E2 production and signaling mechanisms that predict $\beta$-cell dysfunction in a mouse model of type 2 diabetes. Metabolites 11: 58, 2021.

35. Nasrallah R, Robertson SJ, Karsh J and Hébert RL: Celecoxib modifies glomerular basement membrane, mesangium and podocytes in OVE26 mice, but ibuprofen is more detrimental. Clin Sci (Lond) 124: 685-694, 2013.

36. Chan PC, Hsiao FC, Chang HM, Wabitsch M and Hsieh PS: Importance of adipocyte cyclooxygenase- 2 and prostaglandin E2-prostaglandin E receptor 3 signaling in the development of obesity-induced adipose tissue inflammation and insulin resistance. FASEB J 30: 2282-2297, 2016.

37. Hsieh PS, Jin JS, Chiang CF, Chan PC, Chen CH and Shih KC: COX-2-mediated inflammation in fat is crucial for obesity-linked insulin resistance and fatty liver. Obesity (Silver Spring) 17: 1150-1157, 2009.

38. Szerafin T, Erdei N, Fulop T, Pasztor ET, Edes I, Koller A and Bagi Z: Increased cyclooxygenase- 2 expression and prostaglandin-mediated dilation in coronary arterioles of patients with diabetes mellitus. Circ Res 99: e12-e17, 2006.

39. Wang T, Cai H, Zheng W, Michel A, Pawlita M, Milne G, Xiang YB, Gao YT, Li HL, Rothman N, et al: A prospective study of urinary prostaglandin E2 metabolite, helicobacter pylori antibodies, and gastric cancer risk. Clin Infect Dis 64 1380-1386, 2017.

40. Na YR, Jung D, Stakenborg M, Jang H, Gu GJ, Jeong MR, Suh SY, Kim HJ, Kwon YH, Sung TS, et al: Prostaglandin E2 receptor PTGER4-expressing macrophages promote intestinal epithelial barrier regeneration upon inflammation. Gut: Feb 7, 2021 (Epub ahead of print).

41. McCoy JM, Wicks JR and Audoly LP: The role of prostaglandin E2 receptors in the pathogenesis of rheumatoid arthritis. J Clin Invest 110: 651-658, 2002.

42. Fajt ML, Gelhaus SL, Freeman B, Uvalle CE, Trudeau JB, Holguin $\mathrm{F}$ and Wenzel SE: Prostaglandin $\mathrm{D}_{2}$ pathway upregulation: Relation to asthma severity, control, and TH2 inflammation. J Allergy Clin Immunol 131: 1504-1512, 2013.

43. Hoshino T, Nakaya T, Homan T, Tanaka K, Sugimoto Y, Araki W, Narita M, Narumiya S, Suzuki T and Mizushima T: Involvement of prostaglandin E2 in production of amyloid-beta peptides both in vitro and in vivo. J Biol Chem 282: 32676-32688, 2007.

44. Feingold KR, Doerrler W, Dinarello CA, Fiers W and Grunfeld C: Stimulation of lipolysis in cultured fat cells by tumor necrosis factor, interleukin-1, and the interferons is blocked by inhibition of prostaglandin synthesis. Endocrinology 130: 10-16, 1992.

45. Yokota T, Meka CS, Medina KL, Igarashi H, Comp PC Takahashi M, Nishida M, Oritani K, Miyagawa J, Funahashi T, et al: Paracrine regulation of fat cell formation in bone marrow cultures via adiponectin and prostaglandins. J Clin Invest 109: $1303-1310,2002$

46. Forman BM, Tontonoz P, Chen J, Brun RP, Spiegelman BM and Evans RM: 15-Deoxy-delta 12,14-prostaglandin J2 is a ligand for the adipocyte determination factor PPAR gamma. Cell 83: 803-812, 1995

47. Litherland SA, Xie XT, Hutson AD, Wasserfall C, Whittaker DS She JX, Hofig A, Dennis MA, Fuller K, Cook R, et al: Aberrant prostaglandin synthase 2 expression defines an antigen-presenting cell defect for insulin-dependent diabetes mellitus. J Clin Invest 104: 515-523, 1999.

48. Yasui M, Tamura Y, Minami M, Higuchi S, Fujikawa R, Ikedo T, Nagata M, Arai H, Murayama T and Yokode M: The prostaglandin E2 receptor EP4 regulates obesity-related inflammation and insulin sensitivity. PLoS One 10: e0136304, 2015.
49. Edelman MJ, Wang X, Hodgson L, Cheney RT, Baggstrom MQ, Thomas SP, Gajra A, Bertino E, Reckamp KL, Molina J, et al: Phase III randomized, placebo-controlled, double-blind trial of celecoxib in addition to standard chemotherapy for advanced non-small-cell lung cancer with cyclooxygenase-2 overexpression: CALGB 30801 (Alliance). J Clin Oncol 35: 2184-2192, 2017.

50. Pathan SA, Mitra B, Straney LD, Afzal MS, Anjum S, Shukla D, Morley K, Al Hilli SA, Al Rumaihi K, Thomas SH and Cameron PA: Delivering safe and effective analgesia for management of renal colic in the emergency department: A double-blind, multigroup, randomised controlled trial. Lancet 387: 1999-2007, 2016.

51. Bath PM, Woodhouse LJ, Appleton JP, Beridze M, Christensen H, Dineen RA, Duley L, England TJ, Flaherty K, Havard D, et al: Antiplatelet therapy with aspirin, clopidogrel, and dipyridamole versus clopidogrel alone or aspirin and dipyridamole in patients with acute cerebral ischaemia (TARDIS): A randomised, open-label, phase 3 superiority trial. Lancet 391: 850-859, 2018.

52. Norambuena F, Mackenzie S, Bell JG, Callol A, Estévez A and Duncan N: Prostaglandin (F and E, 2- and 3-series) production and cyclooxygenase (COX-2) gene expression of wild and cultured broodstock of Senegalese sole (Solea senegalensis). Gen Comp Endocrinol 177: 256-262, 2012.

53. Wang $\mathrm{X}$, Lin $\mathrm{H}$ and Gu Y: Multiple roles of dihomo- $\gamma$-linolenic acid against proliferation diseases. Lipids Health Dis 11: 25 2012.

54. Sonnweber T, Pizzini A, Nairz M, Weiss G and Tancevski I: Arachidonic acid metabolites in cardiovascular and metabolic diseases. Int J Mol Sci 19: 3285, 2018.

55. Cheng Z, Abayasekara DR and Wathes DC: The effect of supplementation with n-6 polyunsaturated fatty acids on 1-, 2- and 3 -series prostaglandin $\mathrm{F}$ production by ovine uterine epithelial cells. Biochim Biophys Acta 1736: 128-135, 2005.

56. Smith WL, Urade Y and Jakobsson PJ: Enzymes of the cyclooxygenase pathways of prostanoid biosynthesis. Chem Rev 111: 5821-5865, 2011

57. Seibert K, Zhang Y, Leahy K, Hauser S, Masferrer J, Perkins W, Lee L and Isakson P: Pharmacological and biochemical demonstration of the role of cyclooxygenase 2 in inflammation and pain. Proc Natl Acad Sci USA 91: 12013-12017, 1994.

58. Kirkby NS, Zaiss AK, Urquhart P, Jiao J, Austin PJ, Al-Yamani M, Lundberg MH, MacKenzie LS, Warner TD, Nicolaou A, et al: LC-MS/MS confirms that COX-1 drives vascular prostacyclin whilst gene expression pattern reveals non-vascular sites of COX-2 expression. PLoS One 8: e69524, 2013.

59. Kirkby NS, Chan MV, Zaiss AK, Garcia-Vaz E, Jiao J, Berglund LM, Verdu EF, Ahmetaj-Shala B, Wallace JL, Herschman HR, et al: Systematic study of constitutive cyclooxygenase-2 expression: Role of NF- $\kappa \mathrm{B}$ and NFAT transcriptional pathways. Proc Natl Acad Sci A 113: 434-439, 2016.

60. Smith WL, DeWitt DL and Garavito RM: Cyclooxygenases: Structural, cellular, and molecular biology. Annu Rev Biochem 69: 145-182, 2000

61. Tilg H, Moschen AR and Roden M: NAFLD and diabetes mellitus. Nat Rev Gastroenterol Hepatol 14: 32-42, 2017.

62. Oakes ND, Cooney GJ, Camilleri S, Chisholm DJ and Kraegen EW: Mechanisms of liver and muscle insulin resistance induced by chronic high-fat feeding. Diabetes 46: 1768-1774, 1997.

63. Krssak M, Brehm A, Bernroider E, Anderwald C, Nowotny P, Dalla Man C, Cobelli C, Cline GW, Shulman GI, Waldhäusl W and Roden M: Alterations in postprandial hepatic glycogen metabolism in type 2 diabetes. Diabetes 53: 3048-3056, 2004.

64. Smith GI, Shankaran M, Yoshino M, Schweitzer GG, Chondronikola M, Beals JW, Okunade AL, Patterson BW, Nyangau E, Field T, et al: Insulin resistance drives hepatic de novo lipogenesis in nonalcoholic fatty liver disease. J Clin Invest 130: 1453-1460, 2020.

65. McQuaid SE, Hodson L, Neville MJ, Dennis AL, Cheeseman J, Humphreys SM, Ruge T, Gilbert M, Fielding BA, Frayn KN and Karpe F: Downregulation of adipose tissue fatty acid trafficking in obesity: A driver for ectopic fat deposition? Diabetes 60: 47-55, 2011

66. Garcia-Monzón C, Lo Iacono O, Mayoral R, GonzálezRodriguez A, Miquilena-Colina ME, Lozano-Rodriguez T, Garcia-Pozo L, Vargas Castrillón J, Casado M, Boscá L, et al: Hepatic insulin resistance is associated with increased apoptosis and fibrogenesis in nonalcoholic steatohepatitis and chronic hepatitis C. J Hepatol 54: 142-152, 2011. 
67. Weisberg SP, McCann D, Desai M, Rosenbaum M, Leibel RL and Ferrante AW Jr: Obesity is associated with macrophage accumulation in adipose tissue. J Clin Invest 112: 1796-1808, 2003.

68. Xu H, Barnes GT, Yang Q, Tan G, Yang D, Chou CJ, Sole J, Nichols A, Ross JS, Tartaglia LA and Chen H: Chronic inflammation in fat plays a crucial role in the development of obesity-related insulin resistance. J Clin Invest 112: 1821-1830, 2003.

69. Cook JR, Langlet F, Kido Y and Accili D: Pathogenesis of selective insulin resistance in isolated hepatocytes. J Biol Chem 290 13972-13980, 2015.

70. Cao Z, Mulvihill MM, Mukhopadhyay P, Xu H, Erdélyi K, Hao E, Holovac E, Haskó G, Cravatt BF, Nomura DK and Pacher P: Monoacylglycerol lipase controls endocannabinoid and eicosanoid signaling and hepatic injury in mice. Gastroenterology 144: 808-817.e15, 2013.

71. Henkel J, Gärtner D, Dorn C, Hellerbrand C, Schanze N, Elz SR and Püschel GP: Oncostatin M produced in Kupffer cells in response to PGE2: Possible contributor to hepatic insulin resistance and steatosis. Lab Invest 91: 1107-1117, 2011.

72. Henkel J, Neuschäfer-Rube F, Pathe-Neuschäfer-Rube A and Püschel GP: Aggravation by prostaglandin E2 of interleukin-6-dependent insulin resistance in hepatocytes. Hepatology 50: 781-790, 2009.

73. Bock G, Chittilapilly E, Basu R, Toffolo G, Cobelli C, Chandramouli V, Landau BR and Rizza RA: Contribution of hepatic and extrahepatic insulin resistance to the pathogenesis of impaired fasting glucose: Role of increased rates of gluconeogenesis. Diabetes 56: 1703-1711, 2007.

74. Wang Y, Yan S, Xiao B, Zuo S, Zhang Q, Chen G, Yu Y, Chen D, Liu Q, Liu Y, et al: Prostaglandin $\mathrm{F}_{2 \alpha}$ facilitates hepatic glucose production through CaMKII $\gamma / \mathrm{p} 38 / \mathrm{FOXO1}$ signaling pathway in fasting and obesity. Diabetes 67: 1748-1760, 2018.

75. Yan S, Zhang Q, Zhong X, Tang J, Wang Y, Yu J, Zhou Y, Zhang J, Guo F, Liu Y, et al: I prostanoid receptor-mediated inflammatory pathway promotes hepatic gluconeogenesis through activation of PKA and inhibition of AKT. Diabetes 63: 2911-2923, 2014.

76. Francés DE, Motiño O, Agrá N, González-Rodríguez Á, Fernández-Álvarez A,Cucarella C, Mayoral R, Castro-SánchezL, García-Casarrubios E, Boscá L, et al: Hepatic cyclooxygenase-2 expression protects against diet-induced steatosis, obesity, and insulin resistance. Diabetes 64: 1522-1531,2015.

77. Petersen KF, Dufour S, Savage DB, Bilz S, Solomon G Yonemitsu S, Cline GW, Befroy D, Zemany L, Kahn BB, et al: The role of skeletal muscle insulin resistance in the pathogenesis of the metabolic syndrome. Proc Natl Acad Sci USA 104: 12587-12594, 2007

78. Banhos Danneskiold-Samsøe N, Sonne SB, Larsen JM Hansen AN, Fjære E, Isidor MS, Petersen S, Henningsen J, Severi I, Sartini L, et al: Overexpression of cyclooxygenase-2 in adipocytes reduces fat accumulation in inguinal white adipose tissue and hepatic steatosis in high-fat fed mice. Sci Rep 9: 8979, 2019.

79. Ceddia RP, Lee D, Maulis MF, Carboneau BA, Threadgill DW, Poffenberger G, Milne G, Boyd KL, Powers AC, McGuinness OP, et al: The PGE2 EP3 receptor regulates dietinduced adiposity in male mice. Endocrinology 157: 220-232, 2016.

80. Garcia-Alonso V, Titos E, Alcaraz-Quiles J, Rius B, Lopategi A López-Vicario C, Jakobsson PJ, Delgado S, Lozano J and Clària J: Prostaglandin E2 exerts multiple regulatory actions on human obese adipose tissue remodeling, inflammation, adaptive thermogenesis and lipolysis. PLoS One 11: e0153751, 2016.

81. Fujitani Y, Aritake K, Kanaoka Y, Goto T, Takahashi N, Fujimori K and Kawada T: Pronounced adipogenesis and increased insulin sensitivity caused by overproduction of prostaglandin D2 in vivo. FEBS J 277: 1410-1419, 2010.

82. Virtue S, Masoodi M, de Weijer BA, van Eijk M, Mok CY, Eiden M, Dale M, Pirraco A, Serlie MJ, Griffin JL and Vidal-Puig A: Prostaglandin profiling reveals a role for haematopoietic prostaglandin $\mathrm{D}$ synthase in adipose tissue macrophage polarisation in mice and humans. Int J Obes (Lond) 39: 1151-1160, 2015.

83. Hernandez-Carretero A, Weber N, La Frano MR, Ying W, Lantero Rodriguez J, Sears DD, Wallenius V, Borgeson E, Newman JW and Osborn O: Obesity-induced changes in lipid mediators persist after weight loss. Int J Obes (Lond) 42: 728-736, 2018

84. Fujimori K, Aritake K, Oishi Y, Nagata N, Maehara T, Lazarus M and Urade Y: L-PGDS-produced PGD2 in premature, but not in mature, adipocytes increases obesity and insulin resistance. Sci Rep 9: 1931, 2019.
85. Fujimori K, Maruyama T, Kamauchi S and Urade $\mathrm{Y}$ : Activation of adipogenesis by lipocalin-type prostaglandin $\mathrm{D}$ synthase-generated $\Delta^{12}-\mathrm{PGJ}_{2}$ acting through PPAR $\gamma$-dependent and independent pathways. Gene 505: 46-52, 2012.

86. Wakai E, Aritake K, Urade Y and Fujimori K: Prostaglandin D2 enhances lipid accumulation through suppression of lipolysis via DP2 (CRTH2) receptors in adipocytes. Biochem Biophys Res Commun 490: 393-399, 2017.

87. Groop LC, Bonadonna RC, DelPrato S, Ratheiser K, Zyck K, Ferrannini E and DeFronzo RA: Glucose and free fatty acid metabolism in non-insulin-dependent diabetes mellitus. Evidence for multiple sites of insulin resistance. J Clin Invest 84: 205-213, 1989.

88. Skurk T, Alberti-Huber C, Herder C and Hauner H: Relationship between adipocyte size and adipokine expression and secretion. J Clin Endocrinol Metab 92: 1023-1033, 2007.

89. Lê KA, Mahurkar S, Alderete TL, Hasson RE, Adam TC Kim JS, Beale E, Xie C, Greenberg AS, Allayee H and Goran MI: Subcutaneous adipose tissue macrophage infiltration is associated with hepatic and visceral fat deposition, hyperinsulinemia, and stimulation of NF- $\kappa B$ stress pathway. Diabetes 60: 2802-2809, 2011.

90. Utriainen T, Takala T, Luotolahti M, Rönnemaa T, Laine H, Ruotsalainen U, Haaparanta M, Nuutila P and Yki-Järvinen H: Insulin resistance characterizes glucose uptake in skeletal muscle but not in the heart in NIDDM. Diabetologia 41: 555-559, 1998

91. Pratipanawatr W, Pratipanawatr T, Cusi K, Berria R, Adams JM Jenkinson CP, Maezono K, DeFronzo RA and Mandarino LJ: Skeletal muscle insulin resistance in normoglycemic subjects with a strong family history of type 2 diabetes is associated with decreased insulin-stimulated insulin receptor substrate-1 tyrosine phosphorylation. Diabetes 50: 2572-2578, 2001.

92. Weyer C, Bogardus C, Mott DM and Pratley RE: The natural history of insulin secretory dysfunction and insulin resistance in the pathogenesis of type 2 diabetes mellitus. J Clin Invest 104 787-794, 1999.

93. Dietze G, Wicklmayr M, Böttger I and Mayer L: Insulin action on glucose uptake into skeletal muscle: Inhibition of endogenous biosynthesis of prostaglandins. FEBS Lett 92: 294-298, 1978.

94. Leighton B, Budohoski L, Lozeman FJ, Challiss RA and Newsholme EA: The effect of prostaglandins E1, E2 and F2 alpha and indomethacin on the sensitivity of glycolysis and glycogen synthesis to insulin in stripped soleus muscles of the rat. Biochem J 227: 337-340, 1985.

95. Coll T, Palomer X, Blanco-Vaca F, Escolà-Gil JC, Sánchez RM, Laguna JC and Vázquez-Carrera M: Cyclooxygenase 2 inhibition exacerbates palmitate-induced inflammation and insulin resistance in skeletal muscle cells. Endocrinology 151: 537-548, 2010.

96. Smith GI, Polidori DC, Yoshino M, Kearney ML, Patterson BW, Mittendorfer B and Klein S: Influence of adiposity, insulin resistance, and intrahepatic triglyceride content on insulin kinetics. J Clin Invest 130: 3305-3314, 2020

97. Solomon TP, Knudsen SH, Karstoft K, Winding K, Holst JJ and Pedersen BK: Examining the effects of hyperglycemia on pancreatic endocrine function in humans: Evidence for in vivo glucotoxicity. J Clin Endocrinol Metab 97: 4682-4691, 2012.

98. Hughan KS, Bonadonna RC, Lee S, Michaliszyn SF and Arslanian SA: $\beta$-Cell lipotoxicity after an overnight intravenous lipid challenge and free fatty acid elevation in African American versus American white overweight/obese adolescents. J Clin Endocrinol Metab 98: 2062-2069, 2013.

99. Goodpaster BH, Thaete FL and Kelley DE: Thigh adipose tissue distribution is associated with insulin resistance in obesity and in type 2 diabetes mellitus. Am J Clin Nutr 71: 885-892, 2000

100. Solini A, Rossi C, Duranti E, Taddei S, Natali A and Virdis A: Saxagliptin prevents vascular remodeling and oxidative stress in $\mathrm{db} / \mathrm{db}$ mice. Role of endothelial nitric oxide synthase uncoupling and cyclooxygenase. Vascul Pharmacol 76: 62-71, 2016.

101. Hundal RS, Petersen KF, Mayerson AB, Randhawa PS, Inzucchi S, Shoelson SE and Shulman GI: Mechanism by which high-dose aspirin improves glucose metabolism in type 2 diabetes. J Clin Invest 109: 1321-1326, 2002.

102. Helmersson J, Vessby B, Larsson A and Basu S: Association of type 2 diabetes with cyclooxygenase-mediated inflammation and oxidative stress in an elderly population. Circulation 109 1729-1734, 2004

103. Kimple ME, Keller MP, Rabaglia MR, Pasker RL, Neuman JC, Truchan NA, Brar HK and Attie AD: Prostaglandin E2 receptor, EP3, is induced in diabetic islets and negatively regulates glucose- and hormone-stimulated insulin secretion. Diabetes 62: 1904-1912, 2013. 
104. Batchu SN, Majumder S, Bowskill BB, White KE, Advani SL, Brijmohan AS, Liu Y, Thai K, Azizi PM, Lee WL and Advani A: Prostaglandin $\mathrm{I} 2$ receptor agonism preserves $\beta$-cell function and attenuates albuminuria through nephrin-dependent mechanisms. Diabetes 65: 1398-1409, 2016

105. Arablou T, Aryaeian N, Valizadeh M, Sharifi F, Hosseini A and Djalali M: The effect of ginger consumption on glycemic status, lipid profile and some inflammatory markers in patients with type 2 diabetes mellitus. Int J Food Sci Nutr 65: 515-520, 2014.

106. Zhu CF, Li GZ, Peng HB, Zhang F, Chen Y and Li Y: Treatment with marine collagen peptides modulates glucose and lipid metabolism in Chinese patients with type 2 diabetes mellitus Appl Physiol Nutr Metab 35: 797-804, 2010.

107. Ceddia RP, Downey JD, Morrison RD, Kraemer MP, Davis SE, Wu J, Lindsley CW, Yin H, Daniels JS and Breyer RM: The effect of the EP3 antagonist DG-041 on male mice with diet-induced obesity. Prostaglandins Other Lipid Mediat 144: 106353, 2019.

108. Weir GC, Gaglia J and Bonner-Weir S: Inadequate $\beta$-cell mass is essential for the pathogenesis of type 2 diabetes. Lancet Diabetes Endocrinol 8: 249-256, 2020.

109. Grodsky GM: A threshold distribution hypothesis for packet storage of insulin and its mathematical modeling. J Clin Invest 51: 2047-2059, 1972.

110. Persaud SJ, Muller D, Belin VD, Kitsou-Mylona I, Asare-Anane H, Papadimitriou A, Burns CJ, Huang GC, Amiel SA and Jones PM: The role of arachidonic acid and its metabolites in insulin secretion from human islets of langerhans. Diabetes 56: 197-203, 2007.

111. Tran PO, Gleason CE, Poitout V and Robertson RP Prostaglandin E(2) mediates inhibition of insulin secretion by interleukin-1beta. J Biol Chem 274: 31245-31248, 1999.

112. Tran PO, Gleason CE and Robertson RP: Inhibition of interleukin-1beta-induced COX-2 and EP3 gene expression by sodium salicylate enhances pancreatic islet beta-cell function Diabetes 51: 1772-1778, 2002

113. Shanmugam N, Todorov IT, Nair I, Omori K, Reddy MA and Natarajan R: Increased expression of cyclooxygenase-2 in human pancreatic islets treated with high glucose or ligands of the advanced glycation endproduct-specific receptor (AGER), and in islets from diabetic mice. Diabetologia 49: 100-107, 2006

114. Persaud SJ, Burns CJ, Belin VD and Jones PM: Glucose-induced regulation of COX-2 expression in human islets of langerhans. Diabetes 53 (Suppl 1): S190-S192, 2004.

115. Shridas P, Zahoor L, Forrest KJ, Layne JD and Webb NR Group X secretory phospholipase A2 regulates insulin secretion through a cyclooxygenase-2-dependent mechanism. J Biol Chem 289: 27410-27417, 2014

116. Seaquist ER, Walseth TF, Nelson DM and Robertson RP. Pertussis toxin-sensitive $G$ protein mediation of PGE2 inhibition of cAMP metabolism and phasic glucose-induced insulin secretion in HIT cells. Diabetes 38: 1439-1445, 1989.

117. Carboneau BA, Allan JA, Townsend SE, Kimple ME, Breyer RM and Gannon M: Opposing effects of prostaglandin E2 receptors EP3 and EP4 on mouse and human $\beta$-cell survival and proliferation. Mol Metab 6: 548-559, 2017

118. Meng ZX, Sun JX, Ling JJ, Lv JH, Zhu DY, Chen Q, Sun YJ and Han X: Prostaglandin E2 regulates Foxo activity via the Akt pathway: Implications for pancreatic islet beta cell dysfunction. Diabetologia 49: 2959-2968, 2006.

119. Anderson SL, Trujillo JM, McDermott M and Saseen JJ: Determining predictors of response to exenatide in type 2 diabetes. J Am Pharm Assoc (2003) 52: 466-471, 2012.

120. Kimple ME, Moss JB, Brar HK, Rosa TC, Truchan NA, Pasker RL, Newgard CB and Casey PJ: Deletion of GaZ protein protects against diet-induced glucose intolerance via expansion of $\beta$-cell mass. J Biol Chem 287: 20344-20355, 2012.

121. Zawalich WS, Zawalich KC and Yamazaki H: Divergent effects of epinephrine and prostaglandin E2 on glucose-induced insulin secretion from perifused rat islets. Metabolism 56: $12-18,2007$.

122. Igoillo-Esteve M, Marselli L, Cunha DA, Ladrière L, Ortis F, Grieco FA, Dotta F, Weir GC, Marchetti P, Eizirik DL and Cnop M: Palmitate induces a pro-inflammatory response in human pancreatic islets that mimics CCL2 expression by beta cells in type 2 diabetes. Diabetologia 53: 1395-1405, 2010

123. Gokulakrishnan K, Mohanavalli KT, Monickaraj F, Mohan V and Balasubramanyam M: Subclinical inflammation/oxidation as revealed by altered gene expression profiles in subjects with impaired glucose tolerance and Type 2 diabetes patients. Mol Cell Biochem 324: 173-181, 2009.
124. Wang G, Liang R, Liu T, Wang L, Zou J, Liu N, Liu Y, Cai X, Liu Y, Ding X, et al: Opposing effects of IL-1 $\beta / C O X-2 / P G E 2$ pathway loop on islets in type 2 diabetes mellitus. Endocr J 66: 691-699, 2019.

125. Pradhan AD, Manson JE, Rifai N, Buring JE and Ridker PM: C-reactive protein, interleukin 6, and risk of developing type 2 diabetes mellitus. JAMA 286: 327-334, 2001

126. Abou-Shousha S, Abd El-Megeed MH and Sultan HK Interleukin-8, ferritin and soluble transferrin receptors in type II diabetes mellitus. Egypt J Immunol 13: 19-25, 2006.

127. Cai W, Qiu C, Zhang H, Chen X, Zhang X, Meng Q and Wei J: Detection of circulating natural antibodies to inflammatory cytokines in type- 2 diabetes and clinical significance. J Inflamm (Lond) 14: 24, 2017.

128. Rahier J, Guiot Y, Goebbels RM, Sempoux C and Henquin JC: Pancreatic beta-cell mass in European subjects with type 2 diabetes. Diabetes Obes Metab 10 (Suppl 4): S32-S42, 2008.

129. Butler AE, Janson J, Bonner-Weir S, Ritzel R, Rizza RA and Butler PC: Beta-cell deficit and increased beta-cell apoptosis in humans with type 2 diabetes. Diabetes 52: 102-110, 2003.

130. Oshima H, Taketo MM and Oshima M: Destruction of pancreatic beta-cells by transgenic induction of prostaglandin E2 in the islets. J Biol Chem 281: 29330-29336, 2006.

131. Kimple ME, Nixon AB, Kelly P, Bailey CL, Young KH, Fields TA and Casey PJ: A role for G(z) in pancreatic islet beta-cell biology. J Biol Chem 280: 31708-31713, 2005.

132. Amior L, Srivastava R, Nano R, Bertuzzi F and Melloul D: The role of Cox-2 and prostaglandin E2 receptor EP3 in pancreatic $\beta$-cell death. FASEB J 33: 4975-4986, 2019.

133. Lewis B, Mancini M, Mattock M, Chait A and Fraser TR: Plasma triglyceride and fatty acid metabolism in diabetes mellitus. Eur J Clin Invest 2: 445-453, 1972

134. Diraison F, Moulin P and Beylot M: Contribution of hepatic de novo lipogenesis and reesterification of plasma non esterified fatty acids to plasma triglyceride synthesis during non-alcoholic fatty liver disease. Diabetes Metab 29: 478-485, 2003.

135. Tirosh A, Shai I, Bitzur R, Kochba I, Tekes-Manova D, Israeli E, Shochat T and Rudich A: Changes in triglyceride levels over time and risk of type 2 diabetes in young men. Diabetes Care 31: 2032-2037, 2008

136. Kashyap S, Belfort R, Gastaldelli A, Pratipanawatr T, Berria R, Pratipanawatr W, Bajaj M, Mandarino L, DeFronzo R and Cusi K: A sustained increase in plasma free fatty acids impairs insulin secretion in nondiabetic subjects genetically predisposed to develop type 2 diabetes. Diabetes 52: 2461-2474, 2003

137. Sakurai M, Takamura T, Ota T, Ando H, Akahori H, Kaji K, Sasaki M, Nakanuma Y, Miura K and Kaneko S: Liver steatosis, but not fibrosis, is associated with insulin resistance in nonalcoholic fatty liver disease. J Gastroenterol 42: 312-317, 2007.

138. Svegliati-Baroni G, Saccomanno S, Rychlicki C, Agostinelli L, De Minicis S, Candelaresi C, Faraci G, Pacetti D, Vivarelli M, Nicolini D, et al: Glucagon-like peptide-1 receptor activation stimulates hepatic lipid oxidation and restores hepatic signalling alteration induced by a high-fat diet in nonalcoholic steatohepatitis. Liver Int 31: 1285-1297, 2011.

139. Arkan MC, Hevener AL, Greten FR, Maeda S, Li ZW, Long JM, Wynshaw-Boris A, Poli G, Olefsky J and Karin M: IKK-beta links inflammation to obesity-induced insulin resistance. Nat Med 11: 191-198, 2005

140. Henkel J, Frede K, Schanze N, Vogel H, Schürmann A, Spruss A, Bergheim I and Püschel GP: Stimulation of fat accumulation in hepatocytes by $\mathrm{PGE}_{2}$-dependent repression of hepatic lipolysis, $\beta$-oxidation and VLDL-synthesis. Lab Invest 92: 1597-1606, 2012.

141. Pérez S, Aspichueta P, Ochoa B and Chico Y: The 2-series prostaglandins suppress VLDL secretion in an inflammatory condition-dependent manner in primary rat hepatocytes. Biochim Biophys Acta 1761: 160-171, 2006.

142. Chung MY, Mah E, Masterjohn C, Noh SK, Park HJ, Clark RM, Park YK, Lee JY and Bruno RS: Green tea lowers hepatic COX-2 and prostaglandin E2 in rats with dietary fat-induced nonalcoholic steatohepatitis. J Med Food 18: 648-655, 2015.

143. Nassir F, Adewole OL, Brunt EM and Abumrad NA: CD36 deletion reduces VLDL secretion, modulates liver prostaglandins, and exacerbates hepatic steatosis in ob/ob mice. J Lipid Res 54: 2988-2997, 2013.

144. Sato N, Kaneko M, Tamura M and Kurumatani H: The prostacyclin analog beraprost sodium ameliorates characteristics of metabolic syndrome in obese Zucker (fatty) rats. Diabetes 59: 1092-1100, 2010. 
145. Duncan BB, Schmidt MI, Pankow JS, Ballantyne CM, Couper D, Vigo A, Hoogeveen R, Folsom AR and Heiss G; Atherosclerosis Risk in Communities Study: Low-grade systemic inflammation and the development of type 2 diabetes: The atherosclerosis risk in communities study. Diabetes 52: 1799-1805, 2003.

146. Haukeland JW, Damăs JK, Konopski Z, Løberg EM, Haaland T, Goverud I, Torjesen PA, Birkeland K, Bjøro K and Aukrust P: Systemic inflammation in nonalcoholic fatty liver disease is characterized by elevated levels of CCL2. J Hepatol 44: 1167-1174, 2006.

147. Kamari Y, Shaish A, Vax E, Shemesh S, Kandel-Kfir M Arbel Y, Olteanu S, Barshack I, Dotan S, Voronov E, et al: Lack of interleukin-1 $\alpha$ or interleukin-1 $\beta$ inhibits transformation of steatosis to steatohepatitis and liver fibrosis in hypercholesterolemic mice. J Hepatol 55: 1086-1094, 2011.

148. Masters SL, Dunne A, Subramanian SL, Hull RL, Tannahill GM, Sharp FA, Becker C, Franchi L, Yoshihara E, Chen Z, et al: Activation of the NLRP3 inflammasome by islet amyloid polypeptide provides a mechanism for enhanced IL-1 $\beta$ in type 2 diabetes. Nat Immunol 11: 897-904, 2010.

149. Chitturi S, Abeygunasekera S, Farrell GC, Holmes-Walker J, Hui JM, Fung C, Karim R, Lin R, Samarasinghe D, Liddle C, et al: NASH and insulin resistance: Insulin hypersecretion and specific association with the insulin resistance syndrome. Hepatology 35: 373-379, 2002.

150. Sanyal AJ, Campbell-Sargent C, Mirshahi F, Rizzo WB, Contos MJ, Sterling RK, Luketic VA, Shiffman ML and Clore JN Nonalcoholic steatohepatitis: Association of insulin resistance and mitochondrial abnormalities. Gastroenterology 120 1183-1192, 2001.

151. Yang ZH, Miyahara H, Takeo J and Katayama M: Diet high in fat and sucrose induces rapid onset of obesity-related metabolic syndrome partly through rapid response of genes involved in lipogenesis, insulin signalling and inflammation in mice. Diabetol Metab Syndr 4: 32, 2012.

152. Ren LP, Chan SM, Zeng XY, Laybutt DR, Iseli TJ, Sun RQ, Kraegen EW, Cooney GJ, Turner N and Ye JM: Differing endoplasmic reticulum stress response to excess lipogenesis versus lipid oversupply in relation to hepatic steatosis and insulin resistance. PLoS One 7: e30816, 2012.

153. Brunt EM, Kleiner DE, Wilson LA, Unalp A, Behling CE Lavine JE and Neuschwander-Tetri BA; NASH Clinical Research NetworkA list of members of the Nonalcoholic Steatohepatitis Clinical Research Network can be found in the Appendix: Portal chronic inflammation in nonalcoholic fatty liver disease (NAFLD): A histologic marker of advanced NAFLD-clinicopathologic correlations from the nonalcoholic steatohepatitis clinical research network. Hepatology 49: 809-820, 2009.

154. Angulo P, Keach JC, Batts KP and Lindor KD: Independent predictors of liver fibrosis in patients with nonalcoholic steatohepatitis. Hepatology 30: 1356-1362, 1999.

155. Hossain N, Afendy A, Stepanova M, Nader F, Srishord M, Rafiq N, Goodman Z and Younossi Z: Independent predictors of fibrosis in patients with nonalcoholic fatty liver disease. Clin Gastroenterol Hepatol 7: 1224-1229, 1229.e1-e2, 2009.

156. Zeyda M, Farmer D, Todoric J, Aszmann O, Speiser M, Györi G, Zlabinger GJ and Stulnig TM: Human adipose tissue macrophages are of an anti-inflammatory phenotype but capable of excessive pro-inflammatory mediator production. Int $\mathbf{J}$ Obes (Lond) 31: 1420-1428, 2007

157. Itani SI, Ruderman NB, Schmieder F and Boden G: Lipid-induced insulin resistance in human muscle is associated with changes in diacylglycerol, protein kinase $\mathrm{C}$, and IkappaB-alpha. Diabetes 51: 2005-2011, 2002.

158. Hotamisligil GS, Arner P, Caro JF, Atkinson RL and Spiegelman BM: Increased adipose tissue expression of tumor necrosis factor-alpha in human obesity and insulin resistance. J Clin Invest 95: 2409-2415, 1995.

159. du Plessis J, van Pelt J, Korf H, Mathieu C, van der Schueren B, Lannoo M, Oyen T, Topal B, Fetter G, Nayler S, et al: Association of adipose tissue inflammation with histologic severity of nonalcoholic fatty liver disease. Gastroenterology 149: 635-648.e14, 2015.

160. Paradis V, Perlemuter G, Bonvoust F, Dargere D, Parfait B, Vidaud M, Conti M, Huet S, Ba N, Buffet C and Bedossa P High glucose and hyperinsulinemia stimulate connective tissue growth factor expression: A potential mechanism involved in progression to fibrosis in nonalcoholic steatohepatitis. Hepatology 34: 738-744, 2001

161. Ota T, Takamura T, Kurita S, Matsuzawa N, Kita Y, Uno M, Akahori H, Misu H, Sakurai M, Zen Y, et al: Insulin resistance accelerates a dietary rat model of nonalcoholic steatohepatitis. Gastroenterology 132: 282-293, 2007.
162. Henkel J, Coleman CD, Schraplau A, Jöhrens K, Weiss TS, Jonas W, Schürmann A and Püschel GP: Augmented liver inflammation in a microsomal prostaglandin E synthase 1 (mPGES-1)-deficient diet-induced mouse NASH model. Sci Rep 8: 16127, 2018.

163. Loomba R, Quehenberger O, Armando A and Dennis EA: Polyunsaturated fatty acid metabolites as novel lipidomic biomarkers for noninvasive diagnosis of nonalcoholic steatohepatitis. J Lipid Res 56: 185-192, 2015.

164. Motiño O, Agra N, Brea Contreras R, Dominguez-Moreno M, Garcia-Monzón C, Vargas-Castrillón J, Carnovale CE, Boscá L, Casado M, Mayoral R, et al: Cyclooxygenase-2 expression in hepatocytes attenuates non-alcoholic steatohepatitis and liver fibrosis in mice. Biochim Biophys Acta 1862: 1710-1723, 2016.

165. Kumar S, Srivastava A, Palaia T, Hall C, Lee J, Stevenson M, Zhao CL and Ragolia L: Lipocalin-type prostaglandin D2 synthase deletion induces dyslipidemia and non-alcoholic fatty liver disease. Prostaglandins Other Lipid Mediat 149: 106429, 2020.

166. Kumei S, Yuhki KI, Kojima F, Kashiwagi H, Imamichi Y, Okumura T, Narumiya S and Ushikubi F: Prostaglandin $\mathrm{I}_{2}$ suppresses the development of diet-induced nonalcoholic steatohepatitis in mice. FASEB J 32: 2354-2365, 2018.

167. Meng F, Wang K, Aoyama T, Grivennikov SI, Paik Y, Scholten D, Cong M, Iwaisako K, Liu X, Zhang M, et al: Interleukin-17 signaling in inflammatory, Kupffer cells, and hepatic stellate cells exacerbates liver fibrosis in mice. Gastroenterology 143: 765-776.e3, 2012.

168. Ikejima K, Takei Y, Honda H, Hirose M, Yoshikawa M, Zhang YJ, Lang T, Fukuda T, Yamashina S, Kitamura T and Sato N: Leptin receptor-mediated signaling regulates hepatic fibrogenesis and remodeling of extracellular matrix in the rat. Gastroenterology 122: 1399-1410, 2002.

169. Kim SM, Park KC, Kim HG and Han SJ: Effect of selective cyclooxygenase-2 inhibitor meloxicam on liver fibrosis in rats with ligated common bile ducts. Hepatol Res 38: 800-809, 2008

170. Yu J, Ip E, Dela Peña A, Hou JY, Sesha J, Pera N, Hall P, Kirsch R, Leclercq I and Farrell GC: COX-2 induction in mice with experimental nutritional steatohepatitis: Role as pro-inflammatory mediator. Hepatology 43: 826-836, 2006.

171. Paik YH, Kim JK, Lee JI, Kang SH, Kim DY, An SH, Lee SJ, Lee DK, Han KH, Chon CY, et al: Celecoxib induces hepatic stellate cell apoptosis through inhibition of Akt activation and suppresses hepatic fibrosis in rats. Gut 58: 1517-1527, 2009.

172. Simon TG, Henson J, Osganian S, Masia R, Chan AT, Chung RT and Corey KE: Daily aspirin use associated with reduced risk for fibrosis progression in patients with nonalcoholic fatty liver disease. Clin Gastroenterol Hepatol 17: 2776-2784.e4, 2019.

173. Vilar-Gomez E and Chalasani N: Daily aspirin use reduces risk of fibrosis progression in patients with nonalcoholic fatty liver disease, providing new uses for an old drug. Clin Gastroenterol Hepatol 17: 2651-2653, 2019.

174. Sui G, Cheng G, Yuan J, Hou X, Kong X and Niu H: Interleukin (IL)-13, Prostaglandin E2 (PGE2), and Prostacyclin 2 (PGI2) Activate Hepatic Stellate Cells via Protein kinase C (PKC) pathway in hepatic fibrosis. Med Sci Monit 24: 2134-2141, 2018.

175. Hanson A, Wilhelmsen D and DiStefano JK: The role of long non-coding RNAs (lncRNAs) in the development and progression of fibrosis associated with nonalcoholic fatty liver disease (NAFLD). Noncoding RNA 4: 18, 2018.

176. Kamada Y, Mori K, Matsumoto H, Kiso S, Yoshida Y, Shinzaki S, Hiramatsu N, Ishii M, Moriwaki K, Kawada N, et al: $\mathrm{N}$-Acetylglucosaminyltransferase $\mathrm{V}$ regulates TGF- $\beta$ response in hepatic stellate cells and the progression of steatohepatitis. Glycobiology 22: 778-787, 2012.

177. Hui AY, Leung WK, Chan HL, Chan FK, Go MY, Chan KK, Tang BD, Chu ES and Sung JJ: Effect of celecoxib on experimental liver fibrosis in rat. Liver Int 26: 125-136, 2006.

178. Brea R, Motiño O, Francés D, García-Monzón C, Vargas J, Fernández-Velasco M, Boscá L, Casado M, Martín-Sanz P and Agra N: $\mathrm{PGE}_{2}$ induces apoptosis of hepatic stellate cells and attenuates liver fibrosis in mice by downregulating miR-23a-5p and miR-28a-5p. Biochim Biophys Acta Mol Basis Dis 1864: 325-337, 2018.

179. Hui AY, Dannenberg AJ, Sung JJ, Subbaramaiah K, Du B, Olinga P and Friedman SL: Prostaglandin E2 inhibits transforming growth factor beta 1-mediated induction of collagen alpha 1(I) in hepatic stellate cells. J Hepatol 41: 251-258, 2004.

This work is licensed under a Creative Commons Attribution-NonCommercial-NoDerivatives 4.0 International (CC BY-NC-ND 4.0) License. 